\title{
COVID-19 Drives Consumer Behaviour and Agro-Food Markets towards Healthier and More Sustainable Patterns
}

\author{
Valeria Borsellino ${ }^{1, * \mathbb{D}}$, Sina Ahmadi Kaliji ${ }^{2}$ (D) and Emanuele Schimmenti ${ }^{1}$ (D) \\ 1 Department of Agricultural, Food and Forest Sciences, University of Palermo, 90128 Palermo, Italy; \\ emanuele.schimmenti@unipa.it \\ 2 Department of Agricultural Economics, Sari Agricultural Sciences and Natural Resources University, \\ Sari 48181, Iran; S.ahmadikaliji@stu.sanru.ac.ir \\ * Correspondence: valeria.borsellino@unipa.it
}

Received: 17 September 2020; Accepted: 9 October 2020; Published: 12 October 2020

\begin{abstract}
This study examines the extant state of research into our understanding of the impact of the coronavirus pandemic in its early stages on food-purchasing behaviour. As such, it includes a summary and categorisation of the findings, extending to consumption preferences worldwide. After the indiscriminate stockpiling of food, which was witnessed in many countries following the implementation of the lockdown, the impact of COVID-19 (COronaVIrus Disease-2019) on consumer habits has inversely varied in function of personal attitudes, individual and household experiences, and characteristics. Specific contexts, and the financial, economic, and logistic nature of these contexts, have also been found to be of relevance in examining the research relating to the coronavirus pandemic and food-purchasing behaviour. Concurrent with the pandemic, some worldwide trends have emerged-home cooking has been rediscovered, leading to an increase in the demand for staple foodstuffs, and purchases from small, local retailers and online food shopping have been accorded preferential treatment. Despite price volatility and concern about future household incomes, a significant proportion of consumers have shifted to buying healthier, more sustainable food. Moreover, food wastage has seen a notable decrease in volume. Such an occasion should be strategically exploited by manufacturers and retailers in satisfying this consumer demand. Finally, the COVID-19 crisis would seem to offer an unparalleled opportunity to re-engineer the agro-food market by driving the transition toward more sustainable supply and production patterns. Thus, stronger and more equitable partnerships between farmers, manufacturers, retailers, and citizens may be in the process of being forged.
\end{abstract}

Keywords: consumer behaviour; food purchasing behaviour; consumption preferences; domestic food waste; financial crisis; food supply chain

\section{Introduction}

Infectious diseases have been particularly challenging in recent decades, particularly since the beginning of 2020 with the outbreak of the COVID-19 (COronaVIrus Disease-2019) pandemic. Many believe that this pandemic has caused the gravest of problems in public health, economic and financial security, quality of life, and food security around the world as compared to previous pandemics [1]. Many industries have been affected, with the activities of service and manufacturing sectors being suspended to the point of bankruptcy [2]. Numerous governments have created quarantine conditions to limit the spread of COVID-19, urging people to stay at home and leave their home only to meet basic needs such as purchasing food, medical emergencies, and to work (should smart-working not be possible). 
This pandemic is causing economic and social impacts that are more extensive than other major epidemics of the past two decades, including the 2002-2003 SARS (Severe Acute Respiratory Syndrome) epidemic; the 2003 North American BSE (Bovine Spongiform Encephalopathy) crisis; the 2003-2004 H5N1 avian influenza epidemic; and financial crises such as that in Asia in 1997, the turmoil following the 9/11 attacks in 2001, and the 2007-2009 global financial crisis. Indeed, according to the International Monetary Fund [3], the current pandemic is the worst economic and financial crisis since the Great Recession of 1929. A 4.9\% reduction in world GDP has been estimated for 2020 compared to 2019; of the most important economies suffering losses are the European Union $(-10.2 \%$, with peaks for Italy and Spain, both $-12.8 \%$, and France, $-12.5 \%)$, the United Kingdom $(-10.2 \%)$, Canada $(-8.4 \%)$, and the United States $(-8.0 \%)$. Given that the coronavirus is highly contagious and a vaccine is not yet available on the market, it has wreaked havoc on entire economic sectors due to the forced closure of economic and commercial activities [4]. Many economists believe that the pandemic will shock the supply and demand sides of consumer demand. The former includes disruption to the delivery of products and services, whilst the latter regards the volume of consumption and purchases of products [5].

COVID-19 impedes normal food supply chain (FSC) functions. A complex FSC consists of farmers, processing plants, logistics, wholesalers, and retailers [6]. During the ongoing COVID-19 pandemic, breakdowns or bottlenecks in any part of the FSC have affected other components up and down the chain. The results of recent analyses have revealed that the shock in the labour supply has experienced the greatest decrease [5,7], thereby causing disruption in the supply chain and the dumping or wasting of foodstuffs on farms. This disruption is due to the non-harvesting of crops, an accumulation of products on farms, and disruption to the distribution network [4]. As a result of this FSC disruption (a lack of workforce in packing and distributing products to retailers), the shelves in grocery stores (supermarkets) have on occasion been empty, which has furthermore been due to hoarding and panic buying that, in turn, has led to the shortage of basic foodstuffs [2]. In order to prevent such a shortage, many governments have restricted the sale and export of food and increased the import of basic products [8]. The shortage of supply in retail stores and rising household demand has markedly impacted the price volatility of agricultural products [4]. In the meantime, a huge demand shock in the hotel, restaurant, and catering (Ho.Re.Ca.) sectors has been recorded, thereby exerting a major impact on the food system $[9,10]$.

The current pandemic expansion has and will continue to have an unprecedented negative impact on the present and future livelihoods of households and businesses. According to the definition by Engel et al. [11], consumer behaviour, as a purchasing decision process, is a mental process that is experienced prior to and after purchase. Consumer behaviour is very complex, involving a wide range of behaviours from consumption to disposal [12]. Several factors, including economic, regional diversity, socio-demographic, as well as consumer preferences and attitudes, all affect food consumption [4,13]. Furthermore, a limited household income affects food selection and demand [4]. Empirical evidence has demonstrated that dietary habits are modified under the influence of stress [14]. Other research has revealed that, in non-pandemic times, quality, taste, freshness, price, nutritional value, the production method of foodstuffs, etc. affect the behaviour and preference of food choices; in times of crisis, the relative weight of these factors can vary [15]. Moreover, according to the theories relating to the life cycle and permanent income, current expenditure is affected by expected revenues in the future [16]. This also depends on whether the individual is currently optimistic or pessimistic about the future. Consequently, being less optimistic about the future, people will tend to spend less and save more in the present. In this regard, the results of an empirical study in Japan revealed that pandemics had a major impact on low-income workers, negatively affecting women more than men [17].

Many scholars hold that there will be even more significant changes in consumer behaviour in the aftermath of the pandemic. Understanding the societal response to the COVID-19 phenomenon is, therefore, a pressing matter. On the basis of the assumption that preferences, prices, and income are important factors in the context of shopping behaviour and purchases, Cranfield [4] has stated that ignoring socio-demographical factors (such as gender, age, education, employment status, and 
household composition) make it difficult to understand how COVID-19 influences and will influence the consumer demand for foodstuffs. The results of the study by Chronopoulos et al. [18] in Great Britain (GB; England, Scotland, and Wales) have shown that consumer spending was relatively stable in the early stages of the COVID-19 crisis (18 January to 21 February 2020), discretionary spending was significantly reduced as soon as the lockdown became imminent (22 February to 22 March 2020), and this continued during the lockdown period (23 March to 10 May 2020). Spending responses varied according to the classification of different products and locations, in addition to demographic characteristics (age, income level, and gender) $[19,20]$.

Various studies analysing and predicting changes in consumer behaviour and preferences regarding the COVID-19 crisis have focused on behaviours that are beneficial to consumers' health and consumer preferences [21]. According to Naja and Hamadeh [22], many people have attempted to eat a healthier diet, one rich in fruit and vegetables, during the COVID-19 pandemic. Specifically, results by Long and Khoi [2] have revealed that, during the COVID-19 pandemic in Vietnam, the risk perception had a positive effect on consumers' willingness to stockpile food, irrespective of the price and quality, including food with short expiry dates. These conditions will, therefore, lead to changes in lifestyle, behaviour, and eating habits in the long term also $[10,19,20,23]$.

Currently, there are countries that have managed to markedly reduce the transmission of the COVID-19 disease, as well as countries experiencing an early expansive phase. The aim of this paper is to highlight the effects of the COVID-19 crisis on the consumption of foodstuffs by highlighting the similarities and differences that have been recorded to date in the countries most affected by the pandemic. This paper contains a review of the literature, the aim of which is to stimulate further avenues of research. It is structured in five areas: the impact of the past economic crisis on consumer behaviours; the main sustainability issues of current food consumption patterns; the effect of COVID-19 on agro-food consumption habits, preferences, and trends; the effect on consumer purchasing behaviour and buying modalities; and the effect on domestic food waste.

\section{Experiences of an Economic Crisis}

An economic crisis affects consumers psychologically and financially, being one of the factors driving changes in consumer behaviour [12]. It may, therefore, weaken public and individual attention on environmental and sustainability issues [24]. In the economic crises of recent years, many consumers have made fewer purchases due to feelings of insecurity, fear of reduced job opportunities, and reduced economic activity, leading to empty shopping centres and restaurants. According to Başev [12], many people started to eat in rather than dining out during the 2007-2009 economic crisis, switching from more expensive to cheaper foodstuffs. Moreover, his results demonstrated that, in some cases, there was a marked degree of resistance to modifying purchasing habits.

During an economic crisis, such as the 2008 Greek government debt crisis and the subsequent economic recession, consumers were more inclined to eat snacks and fast food; however, price preference was also important and it negatively influenced more expensive fast food [15]. It has been established that consumers' income is the most important factor in determining consumption behaviour [12,15]. In the case of the 2008 Greek crisis, the quality of the food did not affect the change in consumer behaviour, but the price paid did influence consumer behaviour [15]. The same can also be said regarding the impact of the 2008-2014 economic crisis in Spain-consumer behaviour and daily shopping habits shifted so much that consumers paid more attention to price and barely considered the quality of products [25]. In such circumstances, some changes are temporary and some are more long-term. As documented by the results of Bejar Agrela et al. [25], it was revealed that some Spanish people were wary of exhausting their food supplies due to its scarcity, as occurred in the 1936-1939 civil war, and this effect of the habit of consuming food in crises has lingered to modern times. Similarly, Başev [12] contends that the daily shopping habits of many British shoppers have not been completely abandoned, although the 2007-2009 global financial crisis modified their purchasing and spending habits. For example, the purchasing of red meat and chicken did not decrease, nor were retail fast foods 
preferred to outdoor restaurants. Consumers did not switch their loyalty to their favourite retailers but expressed their preference for low-cost retailers. Furthermore, changing their preference for cheaper and more staple foodstuffs did not affect all consumers as some consumers continued with their typical behaviour. Finally, in terms of sustainability, it is of note that the preference of many for healthier, organic, and environmentally friendly food did not change despite the 2007-2009 crisis because their consumption was perceived as conferring health benefits on consumers [12].

\section{The Sustainability of Food Consumption Issues}

The issue of sustainable food consumption patterns, as debated by researchers and policymakers, is currently very topical [26-29]. Food consumption plays a crucial role in creating a sustainable food sector. Since consumers are the final link in food supply chains, they influence food systems through their own food choices and eating habits [30]. Thus, the phenomenon of food consumption has the potential to substantially influence the environment, the economy, and the well-being of society [30-33]. Indeed, as the global population grows to occupy urban spaces, thereby creating additional demand for agricultural production, sustainability issues relating to the food sector arise; some of these include the industrialization of agriculture, the globalization of the agri-food trade, the increasing intake of animal protein in Western diet patterns, the spread of eating habits involving increasingly processed products, and increasing food wastage. All these issues increase the overall pressure on natural resources [34] with consequences for global climate change, resulting in increasing greenhouse gas emissions (GHGE) [31,35].

The substantial impact of the food sector on the environment occurs in the production phase in particular-the Food and Agriculture Organization (FAO) [36] has estimated that agriculture in 2017 contributed by approximately $20 \%$ to the world GHGE by means of its human activities. According to Rosenzweig et al. [35], the percentage contribution of the entire food system to global GHGE emissions was $21-37 \%$ during the 2007-2016 period. Similarly, Poore and Nemecek [37] have estimated that every year approximately $26 \%$ of world GHGE is derived from food production and nearly $6 \%$ from foodstuffs that are lost in supply chains or wasted by consumers. In summary, current food production and consumption habits are unsustainable, and there is a clear need to move towards more sustainable diets and food systems. Indeed, every actor throughout the entire food supply chain (from production (agriculture), manufacturing, distribution and retail, consumption, until final disposal) should be held to support sustainable food production and consumption patterns, as stated with the FAO definition of sustainable diets. This is as follows: " ... diets with low environmental impacts which contribute to food and nutrition security and to healthy life for present and future generations. Sustainable diets are protective and respectful of biodiversity and ecosystems, culturally acceptable, accessible, economically fair and affordable; nutritionally adequate, safe and healthy; while optimizing natural and human resources" [38]. The above definition supports the inseparable environmental and health impact of dietary habits. Moreover, in order to underline the health aspects of a sustainable diet, Mertens et al. [39] have introduced the concept of a SHARP diet whose main features comprise environmentally sustainable, healthy, affordable, reliable (in terms of demand and supply), and preferable elements for consumers according to food preferences and cultural norms.

Similarly, recent studies have suggested that animal-based foods have a higher impact on the environment than those of plant origin $[27,37,40,41]$; the latter also reap greater benefits to health than the former. Indeed, meat production harms the environment through greater GHGE [42,43] than crop production, while meat consumption is believed to jeopardise health by increasing the risk of chronic diseases [44,45]. In contrast, the consumption of fruit, vegetables, and whole grains, in addition to a limited intake of saturated fats, trans fats, sugars, and salt, assists in maintaining health and preventing disease [46,47].

Reducing the negative impacts of current food consumption behaviour is possible through dietary changes (by substituting specific meat and dairy products with fruit and vegetables) $[27,48,49]$ and through technology advances at the farm level [50-52]. Reducing GHGE associated with producing 
red meat seems to comprise the most effective strategy to lowering any climatic impact and the dietary emissions of meat consumption, without modifying consumer behaviour $[43,53,54]$.

The option of reducing meat production and consumption is the most discussed issue in academic debate [55]. However, van Dooren and colleagues [56] have concluded that, in addition to meat and dairy products, snacks and drinks can also contribute significantly to the GHGEs of common diets. This, therefore, highlights the need to gradually change current unsustainable consumption and production patterns, moving towards healthier and more environmentally sustainable diets [41]. Another tactic in this strategy is to align consumption habits with those of the WHO and the FAO dietary guidelines by means of other strategies, e.g., by suggesting a calorie intake in proportion of that required to maintain a healthy body weight [53]. In this regard Burlingame and Dernini [57] have affirmed the importance of the Mediterranean diet as an example of a sustainable diet by virtue of its content and nutrients.

Other issues characterising unsustainable production and consumption patterns need to be discouraged. Examples of the latter include the overconsumption and foods of low nutritional value [56]; both of these can influence overall emissions [29]. In contrast, the consumption of organic food, considered by many as safeguarding the environment and the welfare of future generations [26], has been warmly received by consumers [58], thus contributing in promoting sustainable production and consumption patterns [59].

Pollution and GHGE are also created as a result of a practice, which is widespread among consumers of many developed countries-buying more food than is necessary and managing a household's flow of foodstuffs inefficiently. This greatly exacerbates global food wastage [60], with this increasing amount of food wastage having a negative environmental, social, and monetary impact [61]. Kasavan et al. [62] have stressed that a comprehensive approach to managing the challenge of food wastage is required in promoting sustainable practices in this field. Indeed, referring to preventative measure of food wastage, Papargyropoulou and colleagues [63] have suggested reducing food surpluses throughout the entire food supply chain.

Consumers can play an important role in the transition towards more sustainable food consumption patterns [32] - through planning food purchase, storage, preparation, and food consumption [64]. Even general cooking skills have been mentioned in the debate about minimizing food wastage, as having only a basic competence in this field can lead to poorly cooked food and hence increased food wastage [65]. Finally, the habit of eating healthier foods will encourage the development of sustainable food products, which in turn reduces food wastage $[66,67]$.

\section{Patterns and Trends in Agro-Food Consumption during the Early Stages of COVID-19}

\subsection{Agro-Food Consumption Habits and Preferences}

As the economic crisis and the outbreak of the COVID-19 pandemic have affected the FSC and food availability, many have addressed this departure from normality by modifying the reactions and behaviour regarding their choice of food. Bree [21] has reported that developing a new habit usually requires a time period of approximately 3 weeks. The COVID-19 crisis has clearly lasted much more than 3 weeks, and therefore that which started as a change in consumer behaviour has now morphed into a habit. Moreover, this change in behaviour will continue in proportion to the lasting benefit enjoyed by customers [21].

According to the EY Future Consumer Index by Rogers and Cosgrove [68], of the five consumer segments to assume importance when the COVID-19 crisis can be said to have passed, $28 \%$ of cautiously extravagant consumers ( $25 \%$ of the 4859 consumers surveyed in the USA, Canada, the United Kingdom, France, and Germany during the week starting 6 April 2020) will change their eating habits as a result of COVID-19 whilst only $14 \%$ of get to normal consumers (31\%) envisage that their eating habits would change. Specifically, the former group envisaged increasing their expenditure (by between $+15-55 \%$ ), especially on restaurant food and to a lesser extent fresh food, ready meals, alcoholic beverages, frozen 
food, canned and dried food, and beverages (Figure 1). By contrast, the latter group did not envisage increasing their expenditure of food shopping (between $+1-3 \%$ ).

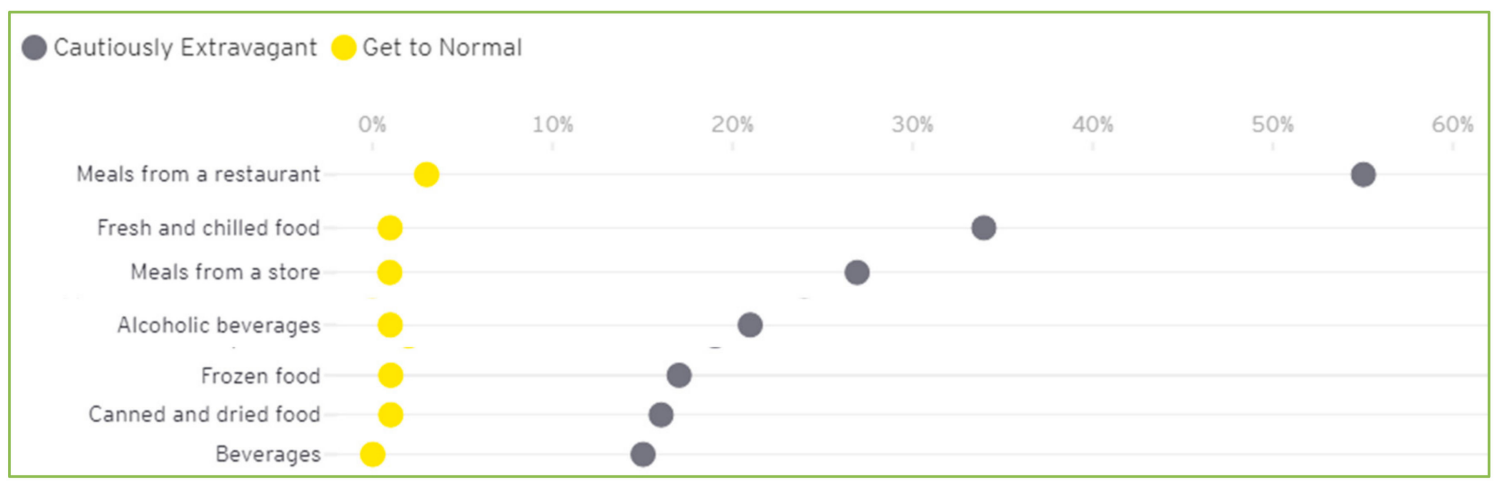

Figure 1. Consumer spending expectations as a result of COVID-19 (\% of segment). Source: Rogers and Cosgrove [68].

Hubbub [69] research has shown that approximately $90 \%$ of a representative sample of 2000 adults surveyed in the United Kingdom have changed their cooking and eating habits since the imposition of the national lockdown on 16 March 2020. These changes included spending more time cooking with family or neighbours (47\%); enjoying cooking at home (44\%); and "sharing" virtual meals over Zoom, Skype, Facetime, etc. (40\%). Moreover, the people interviewed planned to continue with their new shopping and cooking habits after lockdown. These new-found eating habits include improved meal planning using up cupboard staples, freezing food/meals, and making greater use of leftovers (Table 1). Hubbub [69] research also confirmed that many people did not consume as much fresh fruit and vegetables as usual (31\%), minimising their contact with shops, while some also reduced their dairy/egg intake during the lockdown period (15\%). Shortages (Table 2) and difficulties in locating staple food items compelled many to experiment with new recipes (22\%). Finally, it is worth noting there are signs that these new behaviours will continue when the restrictions have been substantially lifted, albeit to a lesser extent.

Table 1. Shopping and cooking habits during and after the COVID-19 lockdown (\%).

\begin{tabular}{ccc} 
Habits & Currently Doing & $\begin{array}{c}\text { Planning to Continue Once } \\
\text { Restrictions Lift }\end{array}$ \\
\hline Shopping less frequently & 44 & 25 \\
Planning meals more carefully & 35 & 30 \\
Consuming food left in the cupboard for a long time & 33 & 25 \\
Using the freezer more & 30 & 20 \\
Buying foods with a longer shelf life & 24 & 17 \\
Eating more leftovers & 23 & 19 \\
Cooking new dishes & 22 & 17 \\
Freezing new dishes & 18 & 13 \\
Shopping online more & 16 & 10 \\
Batch cooking & 16 & 12 \\
Growing food for the first time & 5 & 4 \\
Composting for the first time & 4 & 3 \\
\hline
\end{tabular}

Source: Hubbub [69]. 
Table 2. Food shortages during the COVID-19 lockdown.

\begin{tabular}{cc}
\hline Food Item & $\mathbf{\%}$ \\
\hline Dried starches such as rice and pasta & 48 \\
Eggs & 45 \\
Flour & 44 \\
Tinned vegetables, i.e., tomatoes, sweetcorn & 37 \\
Fresh meat & 27 \\
Dairy produce & 26 \\
Fresh vegetables & 23 \\
Fresh fruit & 22 \\
Frozen vegetables & 18 \\
Ready meals & 12 \\
Pizzas & 11 \\
Other & 6 \\
\hline
\end{tabular}

Source: Hubbub [69].

A study by Datassential [70] of 1000 consumers in the United States that was conducted on 10 March 2020 revealed that $69 \%$ of people preferred to cook at home and $54 \%$ did not prefer to eat at sit-down restaurants (Figure 2). Moreover, according to a quantitative survey conducted online on 2 April 2020, many Americans spent much time engaging in household activities, such as cooking and baking [71]. Greater confidence and families taking pleasure in cooking together, with higher expectations of cooking more after the pandemic to save money and enjoy a healthier diet, were also reported [71].

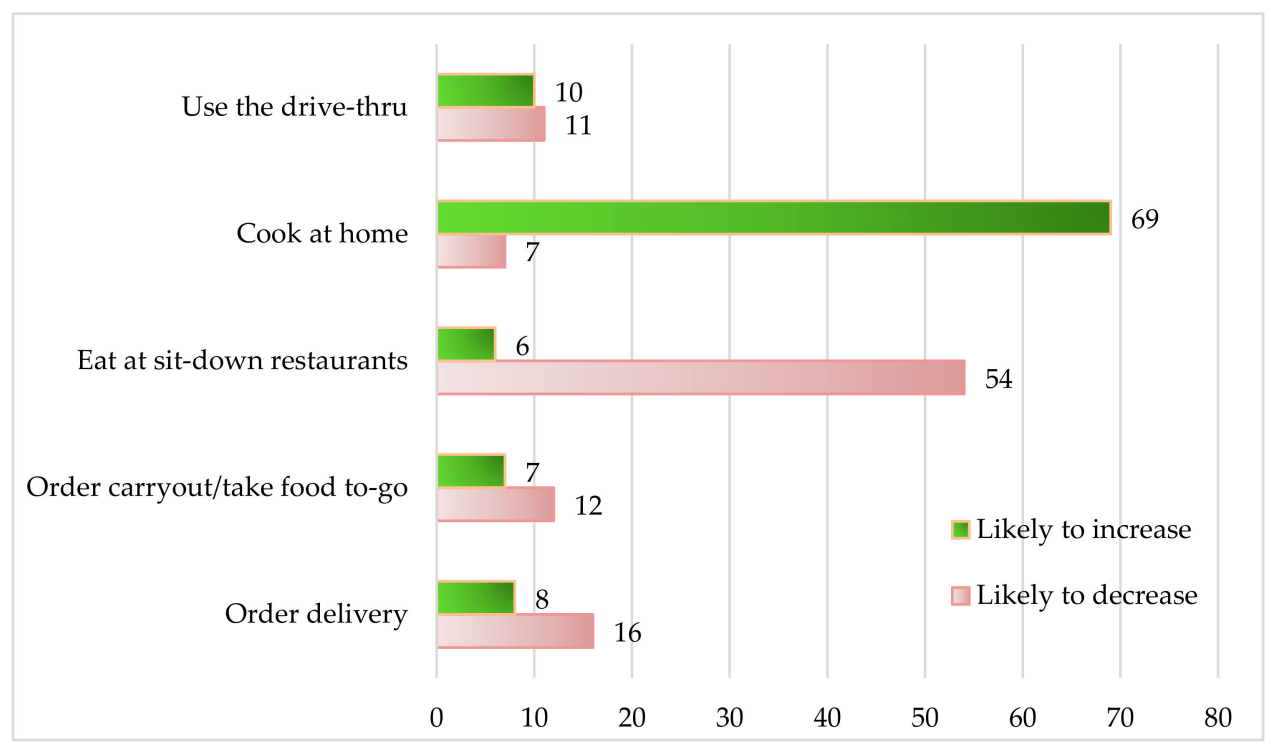

Figure 2. Consumer preferences for full-service restaurants (\%). Source: Datassential [70].

Coffey et al. [72] have investigated the effect of the pandemic on consumption in three scenarios: the new normal, maintaining social distancing and observing new cases of COVID-19; a second wave of infection, leading to a further lockdown; and the situation in which a vaccine is available. According to these scenarios, household consumption in Ireland has been estimated to be $13 \%, 20 \%$, and $12 \%$, respectively, which is lower than in 2019. This reduction was estimated to be at $1 \%, 4 \%$, and $2 \%$, respectively, regarding food consumption and $18 \%, 22 \%$, and $14 \%$ for drinks and tobacco. In their study of Denmark and Sweden, Andersen et al. [73] estimated a significant reduction in consumers' spending during the Danish lockdown period commencing 11 March 2020, which was estimated to be approximately $25 \%$. They also concluded that the shutdown in Denmark reduced spending by approximately $10 \%$ among young people, with increased spending by about $5 \%$ among the elderly. 
Analysing the results by Mintel (www.mintel.com) of their research in the USA, Piek [74] highlighted that, between 6 and 12 March 2020, approximately 25\% of adults stored food and other essentials, and this percentage increased as the quarantine spread over the USA. In addition to modifications in consumer behaviour, changes also occurred regarding their preferences. Consumers were looking for more durable products such as canned, dried, and frozen foods. Similarly, and according to Schmidt et al. [75], consumer preferences have shifted to long-lasting products such as packet soups, canned vegetables, and Ultra-High Temperature processing (UHT) pasteurized milk. Notwithstanding criticalities due to processing procedures and their nutritional value (they are often high in salt, sugar, and saturated fats), these products have proved to be fundamental in satisfying global food requirements during the COVID-19 emergency [21]. Moreover, many people are looking for snack foods, processed bread, and packaged meals to minimise contact with the pandemic and indulge in some comfort eating. This is in contrast to the recent behaviour and preferences of consumers who sought additive-free, fresh foods and beverages in the pre-pandemic era [76]. Indeed, it can be stated that, in times of economic recession, consumers' preferences have tended towards inexpensive shelf-stable and frozen foods. This change in behaviour during the spread of coronavirus has paralleled recessionary economic behaviour-many consumers' preferences for budget-friendly foods have favoured long-life products and larger portions [76].

Analysing Nielsen's data (www.nielsen.com), Devitt [76] reported that, from the end of January to the end of March 2020, there were the following increases in the USA: pasta sales increased by $199 \%$, macaroni and cheese by $176 \%$, lasagne and pizza by $126 \%$, and ramen (Japanese noodle soup) by $117 \%$, while the meat category (i.e., non-plant-based) only grew by $31 \%$. Due to the increase in home cooking, the sale of meat flourished in this period, especially poultry, and the sale of beef and pork was also above average in the same period. In particular, sales of hot dogs, sausages, and bacon grew by about $100 \%$ in the same period. Plant-based meat sales also grew by approximately $70 \%$, especially frozen and fresh products. Demand for flour, sugar, and other ingredients (baking mixes, chocolate and flavoured chips, baking soda, frosting (icing), etc.) also increased due to an increase in bread-baking and making desserts at home.

Table 3 shows the top 10 food and beverage sales categories in the USA in the first quarter of 2020. As can be seen, sales of beef, chicken, cheese, cow's milk, and alcoholic and non-alcoholic beverages increased; this may have been due to an increase in eating meals at home [74].

Table 3. Top 10 foods and drinks sold in the USA (USD millions).

\begin{tabular}{cccccc}
\hline \multicolumn{2}{c}{ Week Ending } & \multicolumn{2}{c}{ 25/1/2020 } & Week Ending $\mathbf{2 2 / 2 / 2 0 2 0}$ & \multicolumn{2}{c}{ Week Ending 21/3/2020 } \\
\hline Category & Sales & Category & Sales & Category & Sales \\
\hline Beef & 507 & Beef & 529 & Beef & 1042 \\
Beer & 489 & Beer & 508 & Beer & 740 \\
Soft drinks & 474 & Soft drinks & 484 & Chicken & 707 \\
Chicken & 448 & Chicken & 438 & Soft drinks & 652 \\
Cow's milk & 242 & Chocolate & 290 & Cheese & 373 \\
Energy drinks & 240 & Energy drinks & 254 & Still wine & 350 \\
Chocolate & 232 & Cow's milk & 238 & Cow's milk & 340 \\
Still wine & 217 & Still wine & 230 & Chocolate & 314 \\
Cheese & 206 & Cheese & 202 & Water & 311 \\
Coffee & 176 & Coffee & 180 & RTE *ereal & 307 \\
\hline
\end{tabular}

* Ready-to-eat. Source: Piek [74], using data provided by Nielsen.

Analysing the Kantar data (www.kantar.com), Traldi [77] commented that the pandemic has also affected the behaviour and preferences of Latin American consumers, who typically possess a preference for appetising and fresh foods such as natural extracts, sauces, and spices. For example, the demand for products such as processed bread rose by about $50 \%$ and approximately $15 \%$ for sausages in Brazil. The demand for ready-made juices, beer, and soft drinks also increased by $15 \%, 10 \%$, and $6 \%$, 
respectively, between January and February 2020. Despite these increases, demand for products such as fermented milk, yoghurt, and soy drinks decreased by $21 \%, 17 \%$, and $7 \%$, respectively, in the same period. Retail sales of beans, rice, and eggs in Mexico increased by about $400 \%$ in the first two weeks of March 2020, and demand for canned food (especially sardines, herring, and tuna) increased by more than $150 \%$. Similarly, sales of beverages, such as orange juice and powdered beverages, increased significantly [77] early on in the COVID-19 crisis in the central regions of Latin America.

According to Li et al. [78], vegetables, rice, and meat in China were in greatest demand during the early stages of the pandemic; China imposed a mandatory, nationwide quarantine between 23 January and 9 February 2020. Moreover, the results of a survey conducted online on 14-16 February 2020 in China by Ipsos [79] revealed that the purchase of foods such as grains, instant food, fresh food, snacks, and dairy products increased significantly during the pandemic; pre-packed beverages, fruit juices, and vitamin drinks increased slightly in the same period; while alcoholic beverages declined (Figure 3).

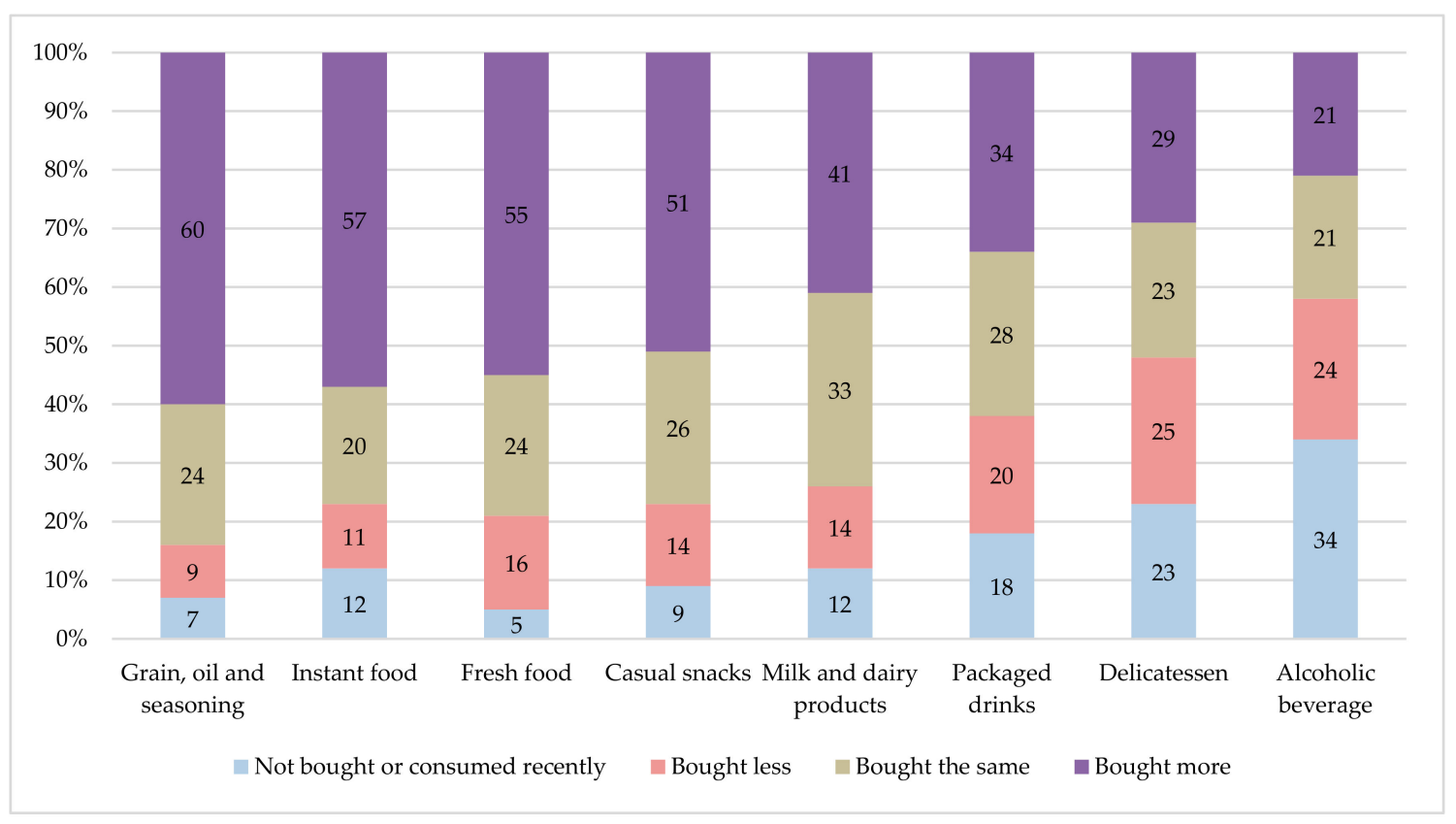

Figure 3. Changes in food purchasing behaviour in China (\%, sample size $=1104)$. Source: Ipsos [79].

Returning to Europe, according to the Organisation for Economic Co-operation and Development (OECD) [80], the cost of some fruit and vegetables increased during the main period of lockdown compared to previously (e.g., potatoes, apples). Moreover, French consumers purchased less perishable fruit and vegetables, preferring long-lasting items such as apples and carrots. According to the Spanish Ministry of Agriculture, Fisheries and Food [81], Spanish consumers increased their shopping for certain products, such as flour $(+147 \%)$ and snacks/nuts $(+15 \%)$, over a six-week period of lockdown restrictions, compared to the same week in the previous year.

Nearby, consumers' habits in Italy also changed compared to the pre-lockdown period (commencing 9 March 2020). The following percentage changes in consumption were recorded in the period of 17 February to 15 March 2020, compared to the same period in 2019: flour $(+79 \%)$, pasta $(+44 \%)$, eggs $(+26 \%)$, canned meats $(+63 \%)$, rice, $(+44 \%)$, and frozen pizza $(+54.3 \%)$, with UHT milk being preferred to fresh milk ( $+29 \%$ and $+4 \%$, respectively) [80]. Moreover, in Italy, from 11 to 17 May 2020, when a new phase of the pandemic can be said to have begun (the reopening of many offices and factories, an easing of restrictions relating to movement in cities, and the requirement of official permission to meet relatives in the same region), consumer attitudes towards different products changed. For example, purchases of wine grew ( $+15 \%$ compared to the 9 March to 4 May 2020 lockdown), especially sparkling wine (+20\%) [82]. Furthermore, forecasts of a panel of 790 
experts interviewed online from 1-6 May 2020 concerning changes in the purchases of Italians in the post-quarantine era elicited the following responses: Made in Italy food (+90\% growth in purchasing), local and zero kilometre food (+81\%), traditional and regional food $(+66 \%)$, and organic and health food $(66 \%)$, as compared to the pre-pandemic situation [83].

\subsection{Health Concerns}

Pre-COVID-19 life changed significantly for many people around the world due to the spread of the pandemic. The requirement to consume nutritional food has emerged in this period in particular because many consumers have become increasingly aware of maintaining good health, and therefore and it has been prioritized. It is of note that consumer behaviour in the pre-pandemic era was already favouring food and dietary supplements as a means of strengthening one's immune system. However, this phenomenon markedly increased in the first few weeks of the pandemic (March 2020) with increasing levels of fear regarding the emergency, with more consumers purchasing products perceived to reap immunological benefits [74]. These concerns have continued to increase, with new behaviours and preferences manifesting themselves among consumers [68,84].

Due to the spread of the pandemic, principles of nutrition, including the timing of meals and the consumption of nutritious food for strengthening one's immune system [85], have increased in importance during the main quarantine period. Scientists have established that the elderly and those with diseases such as obesity and type 2 diabetes are more at risk to COVID-19. Butler and Barrientos [86] have, therefore, recommended the acquisition of healthier eating habits. This includes consuming foodstuffs with lowered levels of saturated fats, sugars, and carbohydrates, and an increased consumption of fibre, whole grains, unsaturated fats, and antioxidants. Accordingly, many consumers are seeking food to boost their immune system by virtue of its importance to health. Piek [74] has stated that about $40 \%$ of Americans prefer food supplements, a datum confirmed by statistical records. Evidence has also suggested that sleep patterns, stress management, and weight gain have benefited from more attention due to job insecurity, anxiety regarding finances, a lack of me-time and space, childcare, and the general fear created by the pandemic. Devitt [76] has indicated that, due to the lockdown and the increasing willingness of people to cook at home, some preferences for less healthy foods may be reduced.

Data relating to Latin America has shown that there is a strong tendency to consume foods with reduced salt, calories, and sugar content because they boost the immune system [77]. Moreover, the results of the study by Ben Hassen et al. [87] in Qatar reported a shift in eating habits that were more inclined towards eating healthier foods due to concerns regarding food safety-approximately $32.4 \%$ of the respondents attempted to decrease their consumption of unhealthy fast foods, and $28.7 \%$ sought to decrease their consumption of candy/sweets, cookies/biscuits, and pastries. Similarly, 21.2\% of an Italian sample, which was surveyed by Scarmozzino and Visioli [88], boosted their consumption of fresh fruit and vegetables during the lockdown period, which officially started on 9 March 2020. This increased consumption should be viewed as positive due to the protective effects of fruit and vegetables as a result of the micronutrient, vitamin, and fibre content [89,90]. Di Renzo et al. [91] recruited 3533 Italian consumers in a survey conducted between 5-24 of April 2020-37.4\% of the study population stated that the consumption of healthier food had increased (fruit, vegetables, nuts, and pulses/legumes) and $29.8 \%$ had decreased their consumption of so-called junk food. A total of $15 \%$ of respondents purchased fruit and vegetables directly from farmers or through organic purchasing groups, while the 18-30-year-olds preferred a Mediterranean diet compared to those below 18 years of age or the elderly. Ruiz-Roso et al. [92] surveyed 820 adolescents (aged 10 to 19 years) from Spain, Italy, Brazil, Colombia, and Chile between 17 April to 25 May 2020. The results highlight positive changes in the dietary patterns-legume, vegetable, and fruit intake significantly increased during COVID-19 confinement compared to the period before confinement, while fast food intake was dramatically reduced. By contrast, as a consequence of boredom and stress produced by COVID-19 confinement, surveyed people also reported a higher consumption of fried and sweet food. 
Healthy eating habits are critical to maintaining health, particularly regarding vulnerable populations such as the elderly and those with comorbidities [93]. The results of the evaluation of 124 diabetic diseases in Poland (July 2020) revealed that the highest increase in food consumption was related to fresh fruit (44\%) and vegetables $(40 \%)$, with the greatest decrease regarding fast food $(32 \%)$ and $(29 \%)$ salty snacks [94].

Moving east from Europe, a study of 5000 consumers across seven Asian countries (Australia, China, India, Indonesia, Japan, South Korea, and Thailand) revealed that consumers paid more attention to their health during the pandemic-more than $75 \%$ of respondents to a survey stated their desire to strengthen their immune systems by doing more exercise and eating a healthier diet. Consequently, the consumption of eggs, dairy products, and bottled water increased, while alcohol and snack consumption declined in these Asian countries [95]. Returning to Europe, food-related behaviours were investigated through an online national survey in the study by Romeo-Arroyo et al. [96] involving 600 consumers in Spain during the COVID-19 epidemic. The results revealed that more than $20 \%$ of the participants were willing to maintain healthy habits after the national lockdown had been substantially lifted. These habits included engaging in sport and cooking. Approximately $15 \%$ of the respondents declared that they were willing to maintain healthier eating habits by increasing their consumption of fruit and vegetables and planning meals more carefully.

\subsection{Price Fluctuations in Agricultural Products}

Price is one of the factors affecting consumer behaviour and purchasing habits, particularly during times of a pandemic and lockdown $[97,98]$. The above-mentioned kinks in the supply chain have affected the global food system [2,4] by impacting on the prices of agricultural products. For example, this impact has been highlighted by fluctuations in the agricultural Producer Price Index (PPI) in China between the first quarters in 2017 (2017 Q1) and 2020 (Q1 2020) (Figure 4). The price index for the first three months of 2020 (139.0) was higher compared with the same quarter in 2017-2019 (98.3 on annual average) [99].

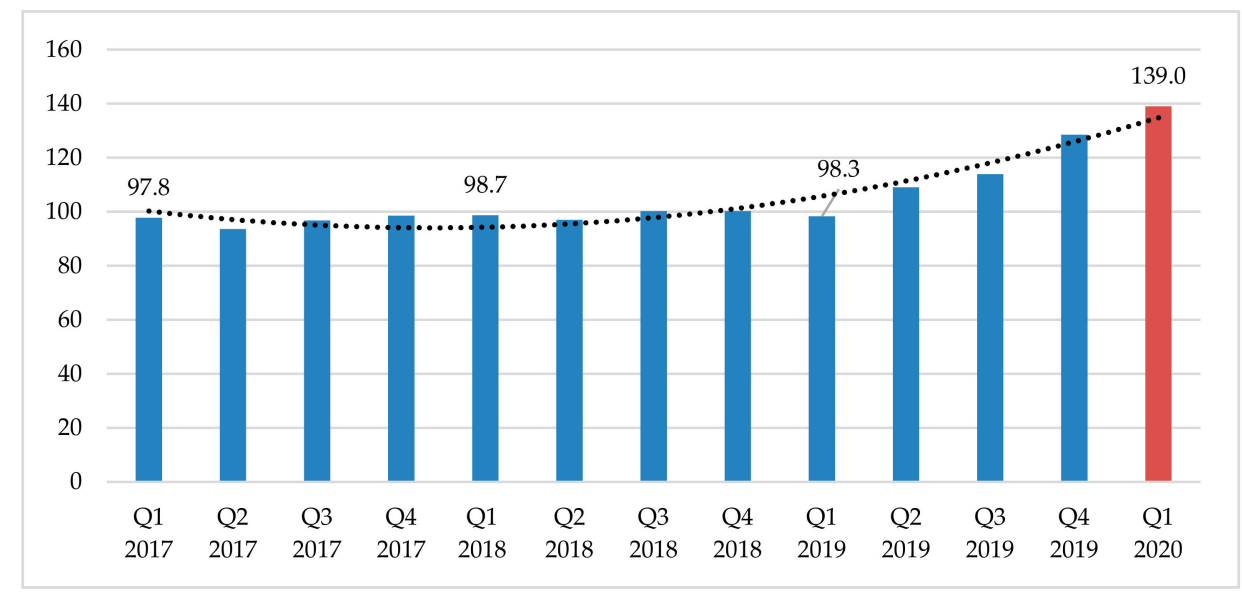

Figure 4. Producer price index (PPI) of agricultural products in China. Source: STATISTA [99].

The trend in the ex-farm prices of fruit and vegetable products in Italy has been influenced by the level of supply, the intensity of demand (domestic and foreign), and the pressure of competition from foreign products. Consequently, different market dynamics were observed for different fruit and vegetable products prior to, during, and after the lockdown period (Table 4) [82]. 
Table 4. Fruit and vegetables: change in average ex-farm, monthly prices.

\begin{tabular}{cccccc}
\hline Product & $\begin{array}{c}\text { JAN 2020 vs. } \\
\text { JAN 2019 }\end{array}$ & $\begin{array}{c}\text { FEB 2020 vs. } \\
\text { FEB 2019 }\end{array}$ & $\begin{array}{c}\text { MAR 2020 vs. } \\
\text { MAR 2019 }\end{array}$ & $\begin{array}{c}\text { APR 2020 vs. } \\
\text { APR 2019 }\end{array}$ & $\begin{array}{c}\text { MAY 2020 vs. } \\
\text { MAY 2019 }\end{array}$ \\
\hline Fuji apples & $9 \%$ & $9 \%$ & $9 \%$ & $15 \%$ & $25 \%$ \\
Golden Delicious apples & $-7 \%$ & $-6 \%$ & $-3 \%$ & $12 \%$ & $31 \%$ \\
Tarocco oranges & $11 \%$ & $9 \%$ & $36 \%$ & $37 \%$ & $24 \%$ \\
Kiwifruit & $39 \%$ & $33 \%$ & $33 \%$ & $49 \%$ & $63 \%$ \\
Strawberries & - & $-3 \%$ & $-7 \%$ & $-5 \%$ & $9 \%$ \\
Peppers & $-47 \%$ & $0 \%$ & $28 \%$ & $46 \%$ & $-43 \%$ \\
Cherry tomatoes & $-18 \%$ & $16 \%$ & $50 \%$ & $16 \%$ & $-33 \%$ \\
Romanesque courgettes & $-17 \%$ & $-13 \%$ & $-30 \%$ & $27 \%$ & $5 \%$ \\
Aubergines & $-33 \%$ & $-19 \%$ & $29 \%$ & $-3 \%$ & $2 \%$ \\
Roman salad & $-11 \%$ & $-10 \%$ & $-1 \%$ & $26 \%$ & $19 \%$ \\
Fennel & $-43 \%$ & $-60 \%$ & $-55 \%$ & $-26 \%$ & $7 \%$ \\
Potatoes & $3 \%$ & $4 \%$ & $3 \%$ & $4 \%$ & $-4 \%$ \\
New potatoes & - & - & $-28 \%$ & $-14 \%$ & $-34 \%$ \\
Asparagus & - & - & $-27 \%$ & $2 \%$ & $-4 \%$ \\
\hline
\end{tabular}

Source: ISMEA [82].

The response to customer demand in grocery stores (selling meat) in the USA is still challenging, not due to a fall in production but on account of difficulties regarding the meat packing industry [100,101]. Indeed, the USA meat packing-processing-distributing capacity has significantly diminished due to shutdowns and slowdowns related to the COVID-19 phenomenon. This has, therefore, driven down prices for livestock (especially beef, pork, and poultry) [102], thereby causing shortages and higher prices for meat products for consumers in retail outlets (Figure 5).

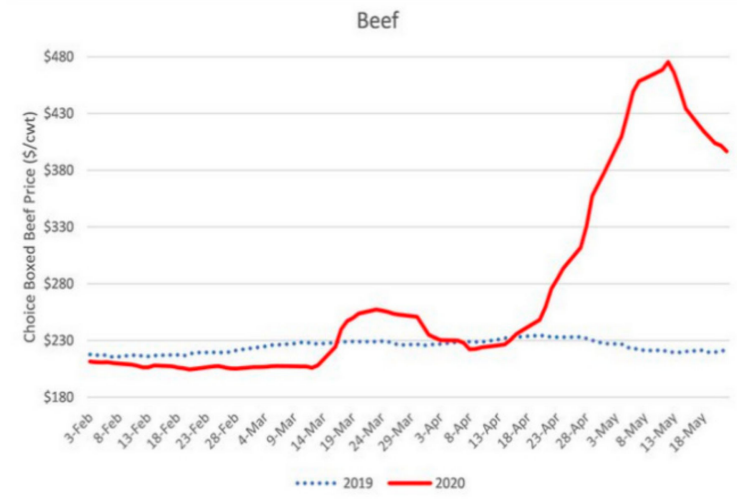

(a)

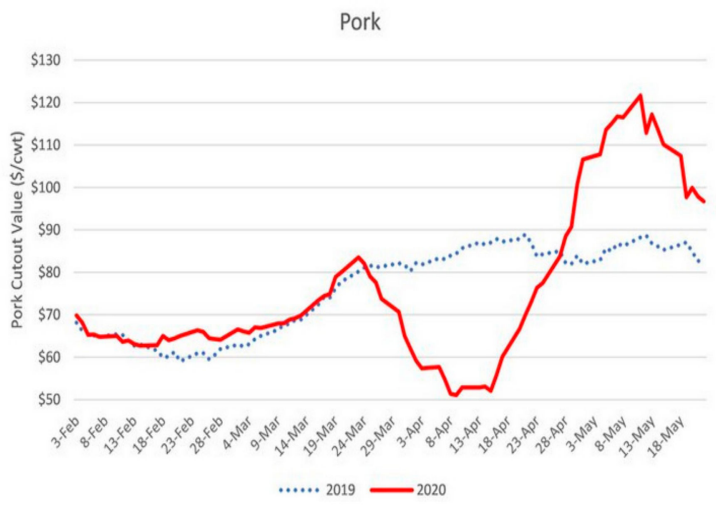

(b)

Figure 5. Wholesale price trend of beef (a) and pork (b) in the USA. Source: Lusk [102].

\section{Agro-Food Purchasing Behaviour and Buying Modalities during the COVID-19 Era}

\subsection{Purchasing Behaviour}

Kirk and Rifkin [103] have demonstrated in their research that the reaction of consumers to a pandemic consists of three stages: reacting by stockpiling goods, coping by maintaining social relations by virtual gatherings, and longer-term adaptation by modifying individual and societal behaviour and consumption. In this regard, Sheth [104] focused on the immediate and long-term pandemic effects on consumer behaviour. The former includes the stockpiling of foodstuffs, improvisation (of daily habits and new consumption methods), pent-up demand, embracing digital technology (to participate in virtual classes etc., including shopping online), home deliveries, the blurring of work-life boundaries, and reunions with family and friends. In the long term, new technologies are being adopted to facilitate work, education, and consumption. Consequently, becoming accustomed to these new technologies will very probably cultivate new habits $[10,23]$. 
Changes are also predicted in the purchasing behaviour segments. On the basis of the EY Future Consumer Index [68], four consumer segments have emerged during the COVID-19 crisis while five consumer segments will emerge as the crisis abates. It is worth noting how the four segments could be transformed into five very different segments as the COVID-19 crisis (Table 5) is isolated. For example, it is envisaged that most consumers in the Save and stockpile segment will migrate towards two new segments-Remain frugal and Cautiously extravagant_-during the pandemic. Many researchers hold that some purchasing behaviours will return to their pre-COVID-19 characteristics [104]. However, some may not because the new models of behaviour are easier to perform, cost less, and are more accessible than was previously the case.

Table 5. Changing consumer segments due to the COVID-19 pandemic.

\begin{tabular}{cccccc}
\hline \multirow{2}{*}{ Present Segments } & \multicolumn{5}{c}{ Next Segments } \\
\cline { 2 - 6 } & $\begin{array}{c}\text { Back with a } \\
\text { Bang (10\%) }\end{array}$ & $\begin{array}{c}\text { Cautiously } \\
\text { Extravagant (25\%) }\end{array}$ & $\begin{array}{c}\text { Stay Frugal } \\
\mathbf{( 2 1 \% )}\end{array}$ & $\begin{array}{c}\text { Get to Normal } \\
\mathbf{( 3 2 \% )}\end{array}$ & $\begin{array}{c}\text { Keep Cutting } \\
\mathbf{( 1 2} \%)\end{array}$ \\
\hline $\begin{array}{c}\text { Hibernate and } \\
\text { spend (11\%) }\end{array}$ & $5 \%$ & $3 \%$ & $2 \%$ & $1 \%$ & - \\
\hline $\begin{array}{c}\text { Save and } \\
\text { stockpile (35\%) }\end{array}$ & $2 \%$ & $12 \%$ & $11 \%$ & $8 \%$ & $2 \%$ \\
\hline $\begin{array}{c}\text { Stay calm, } \\
\text { carry on (27\%) }\end{array}$ & $1 \%$ & $5 \%$ & $2 \%$ & $19 \%$ & - \\
\hline Cut deep (27\%) & $2 \%$ & $5 \%$ & $6 \%$ & $4 \%$ & $10 \%$ \\
\hline
\end{tabular}

There is little doubt that coronavirus has greatly affected the retail sector. The shelves of many retail outlets all over the world were empty due to increased demand in the early days of lockdown [105]. The expansion of COVID-19 worldwide has led to many changes in household behaviour in terms of costs and purchasing, thereby prompting variations in spending patterns and, in some cases, fluctuations in price [106]. With a fluid retail sector, food purchasing habits have changed-with the spread of COVID-19, many consumers face an uncertain future and, consequently, their behaviour will have changed and it may continue to change over an extended period of time [107].

Panic purchasing behaviour can be said to be a reaction to times of fear and uncertainty, leading to the accumulation of basic (rational) goods or an accumulation of unnecessary (irrational) goods. This buying behaviour can lead to a shortage in the supply chain, even if it is not subject to interruptions [108]. Within the context of the pandemic, the retail sector has changed beyond recognition, with supermarkets in New Zealand, Europe, Australia, the USA, and the United Kingdom having introduced changes to reduce panic buying [109]. For example, supermarkets have imposed restrictions on multiple purchases; reduced opening hours; and requested that customers continue shopping as they did prior to the lockdown, resisting the urge to stockpile [109]. The policy of social distancing is prominently displayed throughout all shops and supermarkets-shoppers should shop alone; quickly; and on occasion follow specific entry and exit points, as indicated by floor markings [109]. Recent marketing research in the field of consumer attention and choice has revealed that these constraints can restrict the decision-making process of customers at the point of purchase. On occasion, consumers are selecting top of the range products and brands as opposed to cheaper and lower quality items [110].

Customers' attitudes towards food access have also shifted, depending on the availability of food from channels of sales. According to Li et al. [78], supermarkets in China had the most unfettered access during the early stages of the COVID-19 outbreak (January-February 2020), while farmers' markets were some of the more challenging places for purchasing food in the same period (Table 6). 
Table 6. Food availability based on channels of sales (average rank between 1-5).

\begin{tabular}{ccccc}
\hline \multirow{2}{*}{ Foods } & \multicolumn{3}{c}{ Channels of Sales } \\
\cline { 2 - 5 } & Online & Small Independent Shops & Supermarkets & Farmers' Markets \\
\hline Fresh food & 2.8 & 3.1 & 3.6 & 3.1 \\
Canned food & 3.4 & 3.5 & 3.9 & 2.8 \\
Cooked food & 2.6 & 2.4 & 2.9 & 2.3 \\
Frozen food & 3.3 & 3.3 & 3.9 & 2.9 \\
\hline
\end{tabular}

( $1=$ very difficult; $5=$ very easy). Source: Li et al. [78].

However, the general preference for shopping in the central regions of Latin America has shifted away from more traditional outlets to more "modern" channels, such as super/hypermarkets and drugstores (pharmacy) due to a perception of cleanliness and safety [77]. Hubbub [69] has also highlighted that many consumers in the United Kingdom have adapted their shopping habits in light of the COVID-19 pandemic. During the lockdown, people reduced the number of visits to the shops (44\%) due to the fear factor, instead supporting smaller/local businesses (34\%) and shopping online more than was previously the case (16\%). Some of these revised buying habits may no doubt persist when the restrictions are eased. The vast majority (89\%) of those who have effected these changes say they will continue with at least one of these alternatives instead of using supermarkets (that is, frequenting local shops, including butchers, farm shops, and greengrocers, and ordering home deliveries including fruit/vegetable boxes and milk deliveries) once the pandemic can be said to have abated.

\subsection{Direct Sales}

In addition to direct visits to stores, direct purchasing behaviour has been modified as a result of the COVID-19 pandemic. Many farmers' markets in China lost their customers during the pandemic, unlike independent and small local stores [78], and numerous larger stores, (e.g., hypermarkets, shopping malls, and department stores) suffered the most during the outbreak [79]. Irvine [111] has demonstrated a significant decrease in store visits in the USA from 17 February to 16 March 2020 (of approximately $-80 \%$ ). Chen et al. [112] have used the data relating to daily transactions from 214 cities in China to study the pandemic impact on consumption after China's outbreak in late January 2020. The results of this analysis have confirmed a decrease in Chinese consumption during the 12-week post-outbreak period.

Dunn et al. [113] have estimated consumer spending by using data relating to daily card transactions in the USA - they confirmed that there was a reduction in consumer spending in March 2020 (Figure 6). Approximately 5\% of this reduction regarded retailers, and it continued until April 2020; the trend in transactions in food and beverage service providers also experienced a downward trend. Moreover, these events occurred as the WHO officially declared a global pandemic on 11 March 2020, as shown below by the red vertical line. 


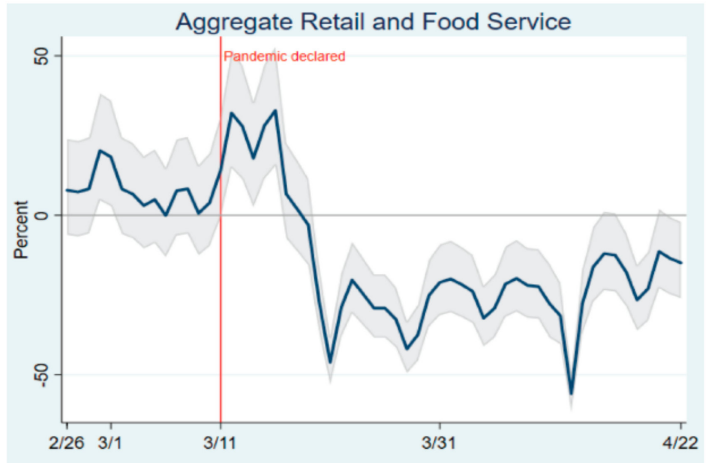

(a)

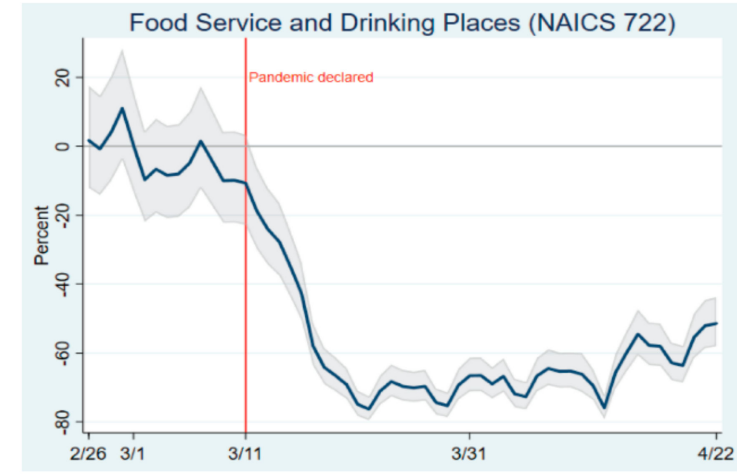

(b)

Figure 6. Sales trend of retail and food services, (a) aggregate retail and food service, (b) food service and drinking places. Source: Dunn et al. [113].

Baker et al. [114] examined the financial transaction data of American households during the January-March 2020 pandemic period-the results confirmed that grocery spending was in sharp decline (Figure 7).

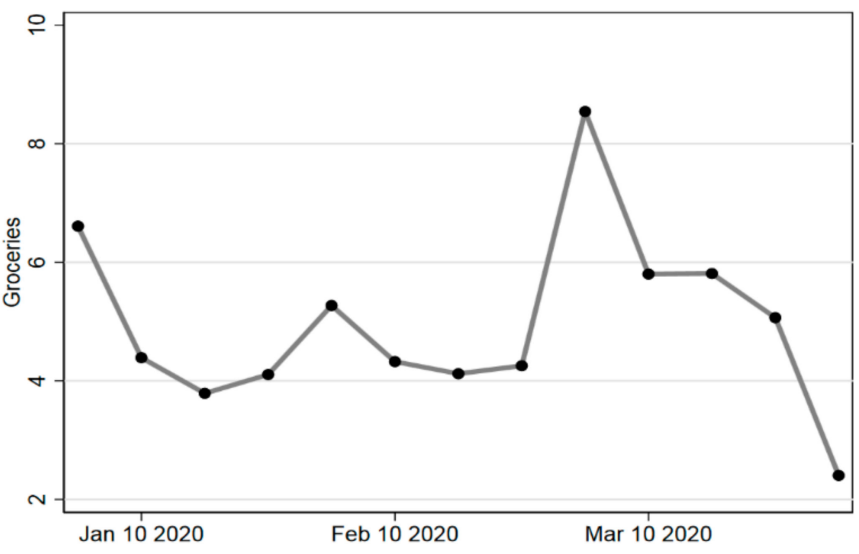

Figure 7. The trend of grocery spending in the USA. Source: Baker et al. [114].

\subsection{Online Shopping}

In accordance with various quarantine rules, the opening hours of shopping centres around the world have been reduced or definitively closed [115]. A burgeoning demand for food products during the lockdown has affected online food deliveries, with some either being delayed or on occasion not shipped. Empirical results from bank card transactions in France $=$ confirmed that shopping online somewhat reduced the pandemic shock [116]. Countries such as the United Kingdom have reduced restrictions on the delivery times of some food retailers as they attempt to restock the shelves with basic foodstuffs. Some supermarkets have also expended efforts in preventing overcrowding on their premises and the consequent spread of the pandemic by offering free delivery [117]. Beyond Europe, China's offline consumption decreased by RMB 1.22 trillion (renminbi (RMB), the currency of the People's Republic of China (PRC)) during the three-month post-outbreak period (February-April 2020), thereby losing $1.2 \%$ of 2019 GDP [112]. Still in Asia, the results of the research by Chauhan and Shah [118] in India have highlighted that the majority of surveyed consumers modified their shopping behaviour (77\%), with 50\% now engaging in mixed-mode buying (e.g., online and in-store). Empirical results by Li et al. [78] revealed that Chinese supermarkets remained a popular choice during January-February 2020 (as confirmed by 35\% of survey respondents), with online food shopping becoming the most popular (38\%) (Figure 8 ). 


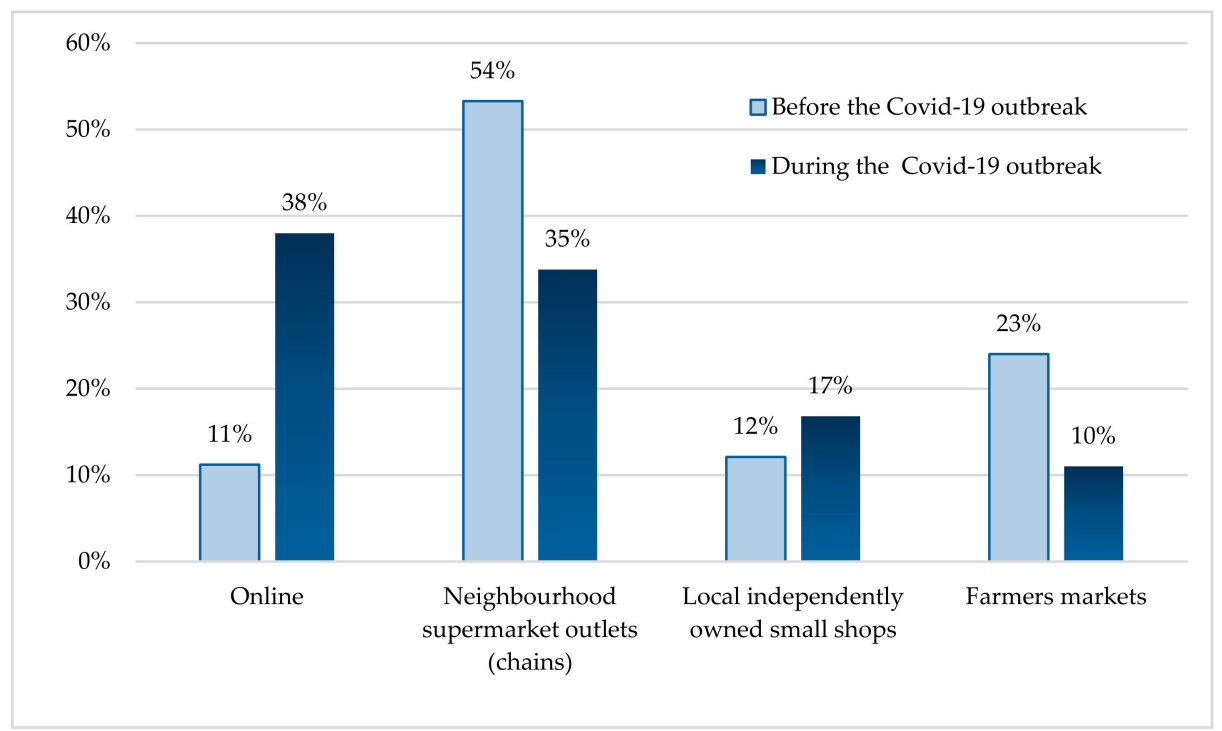

Figure 8. The choice of Chinese shopping channels prior to and after COVID-19 outbreak (January-February 2020). Source: Li et al. [78].

Analyses by Intelligence [119] has shown that changes in purchasing behaviour differ between online and in-store consumers-the former may be more subject to supply shortages. According to data from a market survey developed by Adobe Analytics (https://www.adobe.com/analytics/adobeanalytics.html) in the USA, Piek [74] reported that online grocery shopping increased by as much as $100 \%$ since the lockdown period commenced. This was due in part to restrictions in movement, reducing in-store shopping, resulting in a pronounced tendency to shop online. Thus, new brands and retailers have been favoured, thereby inducing a jolt to the notion of brand loyalty [107]. Many more consumers are eating at home, with a consequent surge in traffic to cooking and recipe websites [120]. Concomitant with the closure of restaurants and the cessation of online food orders, approximately $90 \%$ of food consumption occurs within the home in the USA. This will invariably lead to a drastic change in the way by which foodstuffs are sold in grocery stores, pointing the way to changes in consumer preferences.

\section{The Consumer Habits of Food Waste}

Food wastage has long been a challenge in the spheres of agriculture and food production-even prior to the 2020 pandemic, food wastage and/or losses were an issue due to logistical and climatic issues [121]. The damage wreaked to the traditional supply chain is historically high, and this situation has only been exacerbated by the challenge of the global COVID-19 pandemic. Many countries have been called to promote sustainable development and reduce food waste during the spread of COVID-19, as encouraged by the FAO [122]. Modifying behaviour relating to food waste is also related to factors including the 2009 sovereign debt crisis in Greece [123] and the 2007-2009 economic crisis in Italy $[67,124]$. According to Coldiretti-SWG [125], food wastage in Italy was reduced by $57 \%$ due to this 2007-2009 financial and economic crisis.

Jribi et al. [20] have referred to the socio-economic aspects of food security in periods of quarantine and reducing incomes due to issues of unemployment. Moreover, Hubbub [69] has also contributed to studies in this area-it asserts that, due to restrictions of movement and concerns regarding the cost of many foodstuffs, many U.K. consumers have begun to re-evaluate their attitude towards food $(57 \%)$ and expending efforts to waste less food than would typically be the case (48\%). In this regard, the survey by Grant [126], involving more than 3000 consumers in 15 countries, revealed that more than two-thirds of the respondents focused on limiting food waste during the implementation of stay-at-home orders. According to past studies of consumer behaviour $[127,128]$, and the results of 
research conducted during the pandemic, the prevention of food wastage is more related to personal benefits than environmental concerns. The evaluative results of Jribi et al. [20] regarding food wastage during the two first weeks of COVID-19 outbreak lockdown in Tunisia (commencing 20 March 2020) revealed that the majority of wasted food concerned bakery products, followed by fruit and vegetables. In contrast, the wastage of seafood and fish, meat products, and oilseeds was minimal. The results of the research by Jribi et al. [20] also specified the rationale for food wastage during the same period was due to overcooked food, exceedingly long-term storage in the freezer, overbuying, etc. (Figure 9).

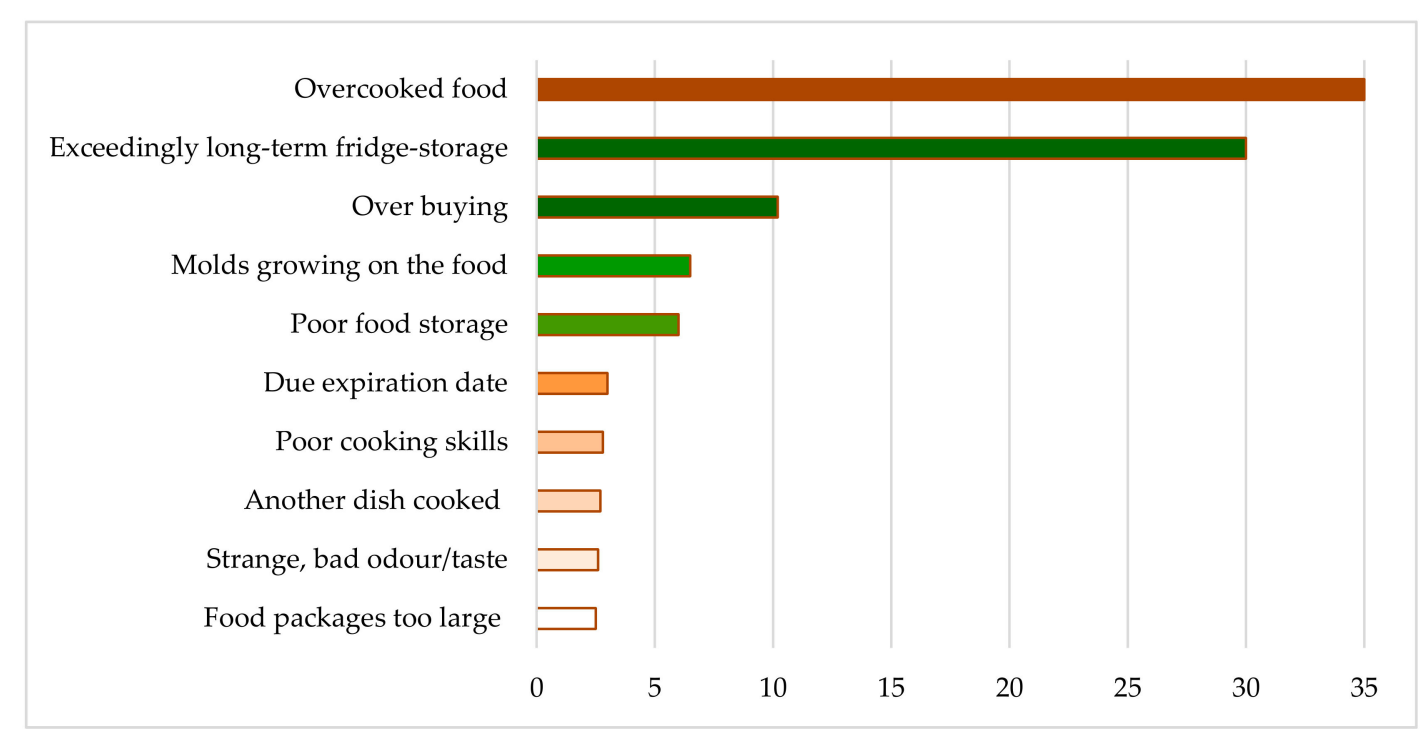

Figure 9. Reason for wasting food during pandemics $(\%, n=284)$. Source: Jribi et al. [20].

\section{Discussion}

The socio-economic impact of COVID-19 has been estimated to be greater, in terms of GDP, employment, and household income, than any other pandemic or financial crisis. Attempting to mitigate the spread of the pandemic, many governments have shut down several economic sectors, such as tourism and entertainment, restaurants, personal services (e.g., hairdressers, beauty salons, gyms, swimming pools, etc.), and some manufacturing facilities. The impact of this cessation of economic activity is linked not only to the spread of the disease itself (regarding those infected) but also to the disease impacting on the behaviour of many actors in the global economy. This study has hitherto examined the extant state of research and summarised and categorised our current understanding of the impact of the coronavirus pandemic in the early stages of the COVID-19 pandemic on food purchasing behaviour and consumption preferences worldwide.

Theoretical implications. Various consumer behaviour patterns, which can be said to be characteristic of the beginning of the COVID-19 pandemic, have been documented; some of these may foreshadow changes that will ultimately revolutionize the lives of many consumers beyond recognition. The authors of this review contend that it highlights the absence of any average effect, instead bearing a specific meaning worldwide in understanding the impact of the COVID-19 crisis on food demand and shopping habits. The impact of COVID-19 varies across the interface of many factors, including individual and household experiences, characteristics, and contexts. The approaches to the crisis inversely vary in function of personal attitudes, as well as the financial, economic, and logistic circumstance of each context. Nonetheless, some worldwide trends have emerged, a summary of which is shown in Table 7. 
Table 7. Summary of the research findings presented in this paper.

\section{Food Consumption Habits and Preferences}

- $\quad$ People share different reactions and behaviour regarding their food choices in this pandemic.

- New behaviour types will continue once the restrictions have been eased, albeit to a lesser extent.

- $\quad$ During the early stages of 2020 pandemic many consumers prefer to cook at home and not eat in restaurants.

- Consumers are looking for long-lasting foodstuffs and to engage in comfort eating.

- Consumers buy less perishable fruit and vegetables in favour of long-life products.

\section{Health Concerns}

- $\quad$ The need to consume healthier food has emerged during the period of the pandemic.

- Many consumers are paying more attention to safeguarding their health during the pandemic.

- Many consumers are looking for foodstuffs to boost their immune system.

- Some preferences for less healthy foods have been reduced as a result of the imposition of the lockdown.

- There is a tendency to consume foodstuffs with a reduced salt, calorie, and sugar content.

- The desire to maintain newly acquired, healthier dietary habits after the easing of the lockdown restrictions is encouraging consumers to increase their intake of fruit and vegetables.

\section{Purchasing Behaviour}

- The transmission of COVID-19 has prompted many changes in household behaviour in terms of costs and purchasing.

- Many consumers are uncertain about the future. Consequently, their purchasing behaviours have changed, and these changes may be long-lasting.

- $\quad$ Some purchasing behaviours will probably return to their previous state; some may not, as newly acquired behaviours are easier, cheaper, and more readily maintained than was the case previously.

- Customers' attitudes towards access to food have also changed, depending on the food availability from by channels of sale.

\section{Direct Sales}

- $\quad$ The behaviour relating to direct purchases has changed as a result of the COVID-19 outbreak.

- $\quad$ Some markets lost their customers during the pandemic, unlike independent and small local stores.

- In-store spending was greatly reduced during the confinement period

- Online shopping.

- $\quad$ Product sales predominantly shifted to home delivery during the lockdown period.

- A burgeoning demand for food products in the lockdown period correlated with an increase in online food deliveries.

- $\quad$ Online shopping has somewhat reduced pandemic shock.

- The tendency to shop online has increased, concurrent with the favouring of hitherto unused brands and retailers, thereby inducing a jolt to brand loyalty.

\section{Consumer Habits Regarding Food Waste}

- Many countries have been called upon to promote sustainable development and reduce food waste during the transmission of COVID-19.

- More consumers have focused on limiting food waste during the pandemic period.

- The rationale for food waste during this period was overcooked food, exceedingly long-term storage in the freezer, overbuying, etc.

Managerial implications. A review of the literature in this field has revealed that changes in behaviour will continue, concurrent with newly-acquired benefits, and that new types of behaviour will continue once the pandemic restrictions have been eased, albeit to a lesser extent. The COVID-19 crisis has, therefore, provided an opportunity for continued developments in the habits of the food consumption and purchasing of the future. The greater importance attached to health by consumers 
offers an attractive pathway towards sustainability. Such an occasion should be strategically exploited by manufacturers and retailers in satisfying consumer demand, especially those consumers seeking to purchase healthier and sustainable food.

The COVID-19 crisis can be said to have offered an unprecedented opportunity for stronger and fairer partnerships between farmers, manufacturers, retailers, and consumers. In this period there has been a surge in consumers making purchases directly from farmers through farm shops and home delivery schemes. Farmers have begun to use digital technologies to facilitate the selling of their products, an approach that has been warmly welcomed by the paying public. This development has highlighted an unparalleled opportunity to consumers and producers alike. Seeking to locate alternative channels of sales (direct sales, milk deliveries, home delivery, online sales, etc.), the paying public could constitute a solution to mitigating and diversifying market risk. In the medium term, the requirement to coexist with the virus will lead to an enhanced use of new technologies Information and Communications Technology (ICT), precision livestock, videoconferencing, etc.), also boosting an increase in companies' income.

\section{Conclusions, Limitations, and Future Research}

The COVID-19 crisis has fostered awareness among people regarding the importance of agro-food products, which have become a staple in all countries that have endured a period of lockdown. Indeed, where it has occurred, numerous problems in the FSC have arisen due, on the one hand, to a shortage in the labour supply and the accumulation and/or loss of production on the farm and, on the other hand, a surplus of demand over supply for various agro-food products. The authors of this paper aspire to having shed some light on the effects of the COVID-19 crisis, the FSC, consumer behaviour, food/grocery services, local food systems, food waste, and major commodity prices.

This study examined the current state of academic research, including that disseminated by public and private research bodies and companies (industry surveys, blogs, etc.). The rationale for this is the desire to document the phenomenon of the COVID-19 pandemic as soon as is practicable in a context of rapidly emerging information, which is located in different public media. In turn, the latter is based on ad hoc reports of leading players in the food and beverage sectors, marketing/public relations companies, and various agricultural organisations. Given the exploratory nature of this study, the choice of topics discussed has been influenced by the authors' personal experiences, scholarship, and individual inclinations as influenced by the surrounding media.

Referring to the findings of this review, the transition towards the sustainability of the current agriculture and food systems (including agri-food markets) is even more necessary in guaranteeing food and nutrition security, particularly in times of crises such as the current pandemic. The findings presented in this paper (the authors contend) have demonstrated that considerations of health have the potential to support behavioural change regarding sustainable diets and promoting sustainable production patterns. State and local governments can increase access to healthy food and decrease access to unhealthy food by enacting laws or regulations. For example, cities can make it easier to establish farmers' markets throughout a community as well as limit or even ban fast food outlets through zoning laws. Governments can also improve residents' diets by adopting healthy procurement policies in order to be able to influence the types of foods available more broadly to the community and provide healthier food to community members. The public health strategies of the future could be designed to reflect such consumer attitudes-the most unfettered access to healthier foods should be a national priority many would assert. The authors of this study feel that governments and the relevant authorities should promote healthier food habits in reducing the susceptibility to and the long-term complications of COVID-19 and future pandemics. One the one hand, these policy reformulations should be directed towards the implementation of the innovations of process and product related to all forms of benign agriculture, in addition to revised ways of organising supply chains; on the other hand, the reformulations should be geared towards the use of levers that can influence the purchasing environment and promote healthier and more sustainable food choices. In this respect, supermarkets, 
food services, and public catering should be involved in the challenge of proposing styles of food consumption, which are adapted to regional, locally rooted contexts. Consumers will, therefore, be able to identify with their contexts, thus assisting in the conservation of cultural diversity. For example, this could be achieved by enhancing the consumption of meat products using sustainable methods, thereby reducing the suffering of intensively farmed animals and the subsequent environmental damage. In order to support public awareness campaigns regarding healthier purchasing and educational programmes, it is also necessary to demand greater transparency from food producers in terms of labelling and reliability in providing correct and comprehensive information about the product, the sustainability of the production processes, and the origin of raw materials. The authors of this paper propose a change of focus in order to maximise food consumption with minimum wastage, in addition to promoting initiatives to facilitate access to food and assist the population, particularly those on low incomes in periods of lockdown. Within this context, the following will assist agri-food markets in achieving food security, environmental sustainability, and economic development: communication and promotion of the role of sustainable diets in reducing food wastage and GHG emissions, and an examination of the performance of local compared to global logistic networks in terms of food loss.

Given the importance of the impact of the COVID-19 pandemic on the global population, the requisite of further studies in this field is self-evident. Certainly, in the three periods of short-, medium-, and long-term, the habits of food consumption preferences will develop along different trajectories. In order to understand future consumer behaviour and satisfy global demand for foodstuffs, the authors of this study believe that prospective studies should focus on topics such as the re-engineering of a more sustainable and a strengthened FSC food security, the minimisation of food waste, unfettered access to food, and healthier eating patterns. Finally, as people responded to the rising of the pandemic by stockpiling essential household items and food products (in anticipation of movement restrictions and supply shortages) due to a feeling of insecurity and the perceived scarcity effect, further studies about the core factor responsible for the panic buying phenomenon would help to identify preventive, appropriate marketing measures and strategies to develop contingency plans. These would be able to address erratic consumer behaviour and mitigate crises side effects, such as panic buying and its related consequences, during future public health emergency situations or natural crises. These are all matters of the utmost urgency and intensity during the 2020 pandemic.

Author Contributions: Conceptualization, V.B., S.A.K. and E.S.; writing-Original draft preparation, V.B., S.A.K. and E.S.; writing-Review and editing, V.B., S.A.K. and E.S. All authors have read and agreed to the published version of the manuscript.

Funding: This research received no external funding.

Conflicts of Interest: The authors declare no conflict of interest.

\section{References}

1. WHO. Coronavirus Disease (COVID-19) Pandemic; WHO: Geneva, Switzerland, 2020.

2. Long, N.N.; Khoi, B.H. An Empirical Study about the Intention to Hoard Food during COVID-19 Pandemic. Eurasia J. Math. Sci. Technol. Educ. 2020, 16, 1-12. [CrossRef]

3. IMF. International Monetary Fund. 2020. Available online: https://www.imf.org/en/News/Articles/2020/ 03/23/pr2098-imf-managing-director-statement-following-a-g20-ministerial-call-on-the-coronavirusemergency (accessed on 12 May 2020).

4. Cranfield, J.A.L. Framing consumer food demand responses in a viral pandemic. Can. J. Agric. Econ. Can. Agroecon. 2020. [CrossRef]

5. Brinca, P.; Duarte, J.B.; Castro, M.F.E. Is the COVID-19 Pandemic a Supply or a Demand Shock? Econ. Synop. 2020, 2020. [CrossRef]

6. Cullen, M.T. COVID-19 and the Risk to Food Supply Chains: How to Respond? Food and Agriculture Organization of the United Nations: Rome, Italy, 2020. 
7. Benzeval, M.; Burton, J.; Crossley, T.F.; Fisher, P.; Jäckle, A.; Low, H.; Read, B. The Idiosyncratic Impact of an Aggregate Shock: The Distributional Consequences of COVID-19; Understanding Society Working Paper Series: Essex, UK. Available online: https://www.understandingsociety.ac.uk/sites/default/files/downloads/ working-papers/2020-09.pdf (accessed on 12 May 2020).

8. Mattioli, A.V.; Sciomer, S.; Cocchi, C. Quarantine during COVID-19 outbreak: Changes in diet and physical activity increase the risk of cardiovascular disease. Nutr. Metab. Cardiovasc. Dis. 2020, 9, 1409-1417. [CrossRef] [PubMed]

9. Lusk, J. Ruminations on Solutions to the COVID Related Food Disruptions. Available online: http: //jaysonlusk.com/blog/2020/5/12/ruminations-on-solutions-to-the-covid-related-food-disruptions (accessed on 12 May 2020).

10. Cohen, M.J. Does the COVID-19 outbreak mark the onset of a sustainable consumption transition? Sustain. Sci. Pract. Policy 2020, 16, 1-3. [CrossRef]

11. Engel, J.F.; Blackwell, R.D.; Miniard, P.W. Consumer Behaviour, 8th ed.; Dryden Press: Oak Brook, IL, USA, 1995.

12. Başev, S.E. Effect of economic crisis on food consumption behaviour of British Consumers. Int. J. Educ. Res. 2014, 2, 289-316.

13. Fieldhouse, P. Food \& Nutrition: Customs and Culture, 2nd ed.; Chapman \& Hall: New York, NY, USA, 1995.

14. Anton, S.D.; Miller, P.M. Do Negative Emotions Predict Alcohol Consumption, Saturated Fat Intake, and Physical Activity in Older Adults? Behav. Modif. 2005, 29, 677-688. [CrossRef]

15. Theodoridou, G.; Tsakiridou, E.; Kalogeras, N.; Mattas, K. The Impact of the Economic Crisis on Greek Consumer Behaviour towards Food Consumption. Int. J. Food Syst. Dyn. 2019, 10, 298-314. [CrossRef]

16. Throop, A.W. Consumer Sentiment: Its Causes and Effects. Econ. Rev. 1992, 1, 35-59.

17. Kikuchi, S.; Kitao, S.; Mikoshiba, M. Heterogeneous Vulnerability to the COVID-19 Crisis and Implications for Inequality in Japan Heterogeneous Vulnerability to the COVID-19 Crisis and Implications for Inequality in Japan; Research Institute of Economy, Trade and Industry (RIETI): Tokyo, Japan, 2020.

18. Chronopoulos, D.K.; Lukas, M.; Wilson, J.O.S. Consumer Spending Responses to the COVID-19 Pandemic: An Assessment of Great Britain. ERC Res. Pap. 2020, 87, 1-38. [CrossRef]

19. Criteo Coronavirus Consumer Trends: Consumer Electronics, Pet Supplies, and More. Available online: https://www.criteo.com/insights/coronavirus-consumer-trends/ (accessed on 25 March 2020).

20. Jribi, S.; Ben-Ismail, H.; Doggui, D.; Debbabi, H. COVID-19 virus outbreak lockdown: What impacts on household food wastage? Environ. Dev. Sustain. 2020, 22, 3939-3955. [CrossRef] [PubMed]

21. Bree, A. How Will Covid-19 Change Our Relationship with Food? Available online: https://nutritionconnect. org/resource-center/how-will-covid-19-change-our-relationship-food (accessed on 14 April 2020).

22. Naja, F.; Hamadeh, R. Nutrition amid the COVID-19 pandemic: A multi-level framework for action. Eur. J. Clin. Nutr. 2020, 5. [CrossRef] [PubMed]

23. Sarkis, J.; Cohen, M.J.; Dewick, P.; Schröder, P. A brave new world: Lessons from the COVID-19 pandemic for transitioning to sustainable supply and production. Resour. Conserv. Recycl. 2020, 159, 104894. [CrossRef] [PubMed]

24. Geels, F.W. The impact of the financial-economic crisis on sustainability transitions: Financial investment, governance and public discourse. Environ. Innov. Soc. Transitions 2013, 6, 67-95. [CrossRef]

25. Bejar-Agrela, M.; Godspower-Diejomaoh, G.; Maurel, L. What Are the Major Changes the Financial Crisis Impacted on the Spanish Consumer Behaviour? 2012. Available online: https://core.ac.uk/download/pdf/ 12521819.pdf (accessed on 14 March 2020).

26. Vermeir, I.; Verbeke, W. Sustainable Food Consumption: Exploring the Consumer "Attitude - Behavioral Intention" Gap. J. Agric. Environ. Ethics 2006, 19, 169-194. [CrossRef]

27. Joyce, A.; Hallett, J.; Hannelly, T.; Carey, G. The impact of nutritional choices on global warming and policy implications: Examining the link between dietary choices and greenhouse gas emissions. Energy Emiss. Control Technol. 2014, 2, 33-43. [CrossRef]

28. Hyland, J.J.; Styles, D.; Jones, D.L.; Williams, A.P. Improving livestock production efficiencies presents a major opportunity to reduce sectoral greenhouse gas emissions. Agric. Syst. 2016, 147, 123-131. [CrossRef]

29. Hyland, J.J.; McCarthy, M.B.; Henchion, M.; McCarthy, S.N. Dietary emissions patterns and their effect on the overall climatic impact of food consumption. Inst. Food Sci. Technol. 2017, 52, 2505-2512. [CrossRef] 
30. Payne, C.L.; Scarborough, P.; Cobiac, L. Do low-carbon-emission diets lead to higher nutritional quality and positive health outcomes? A systematic review of the literature. Public Health Nutr. 2016, 19, $2654-2661$. [CrossRef]

31. Reisch, L.; Eberle, U.; Lorek, S. Sustainable food consumption: An overview of contemporary issues and policies. Sustain. Sci. Pr. Policy 2013, 9, 7-25. [CrossRef]

32. Lim, E.; Arita, S.; Joung, S. Advancing Sustainable Consumption in Korea and Japan-From Re-Orientation of Consumer Behavior to Civic Actions. Sustainability 2019, 11, 6683. [CrossRef]

33. Azzurra, A.; Massimiliano, A.; Angela, M. Measuring sustainable food consumption: A case study on organic food. Sustain. Prod. Consum. 2019, 17, 95-107. [CrossRef]

34. Thøgersen, J. Unsustainable Consumption Basic Causes and Implications for Policy. Eur. Psychol. 2014, 19, 84-95. [CrossRef]

35. Rosenzweig, C.; Mbow, C.; Barioni, L.G.; Benton, T.G.; Herrero, M.; Krishnapillai, M.; Liwenga, E.T.; Pradhan, P.; Rivera-Ferre, M.G.; Sapkota, T.; et al. Climate change responses benefit from a global food system approach. Nat. Food 2020, 1, 94-97. [CrossRef]

36. FAO. The Contribution of Agriculture to Greenhouse Gas Emissions. Available online: http://www.fao.org/ economic/ess/environment/data/emission-shares/en/ (accessed on 18 February 2020).

37. Poore, J.; Nemecek, T. Reducing food's environmental impacts through producers and consumers. Science 2018, 360, 987-992. [CrossRef] [PubMed]

38. FAO. Definition of "sustainable diets". In Proceedings of the International Scientific Symposium "Biodiversity and Sustainable Diets: United against Hunger", Rome, Italy, 3-5 November 2010; 2010.

39. Mertens, E.; Van't-Veer, P.; Hiddink, G.J.; Steijns, J.M.J.M.; Kuijsten, A. Operationalising the health aspects of sustainable diets: A review. Public Health Nutr. 2017, 20, 739-757. [CrossRef] [PubMed]

40. Perignon, M.; Vieux, F.; Soler, L.-G.; Masset, G.; Darmon, N. Improving diet sustainability through evolution of food choices: Review of epidemiological studies on the environmental impact of diets. Nutr. Rev. 2017, 75, 2-17. [CrossRef]

41. van Loo, E.J.; Hoefkens, C.; Verbeke, W. Healthy, sustainable and plant-based eating: Perceived (mis)match and involvement-based consumer segments as targets for future policy. Food Policy 2017, 69, 46-57. [CrossRef]

42. Dagevos, H.; Voordouw, J. Sustainability and meat consumption: Is reduction realistic? Sustain. Sci. Pract. Policy 2013, 9, 60-69. [CrossRef]

43. Macdiarmid, J.I.; Douglas, F.; Campbell, J. Eating like there's no tomorrow: Public awareness of the environmental impact of food and reluctance to eat less meat as part of a sustainable diet. Appetite 2016, 96, 487-493. [CrossRef]

44. Marsh, K.; Saunders, A.; Zeuschner, C. Chapter 8. Red Meat and Health: Evidence Regarding Red Meat, Health, and Chronic Disease Risk. In Impact of Meat Consumption on Health and Environmental Sustainability. Available online: https://www.igi-global.com/chapter/red-meat-and-health/158920 (accessed on 5 October 2020).

45. Wolk, A. Potential health hazards of eating red meat. J. Intern. Med. 2017, 281, 106-122. [CrossRef] [PubMed]

46. World Health Organization. Diet, Nutrition, and the Prevention of Chronic Diseases: Report of a Joint WHO/FAO Expert Consultation; WHO Technical Report Series 916. World Health Organization: Geneva, Switzerland. Available online: https://www.who.int/dietphysicalactivity/publications/trs916/download/en/ (accessed on 5 October 2020).

47. Waxman, A. WHO global strategy on diet, physical activity and health. Food Nutr. 2004, 25, $292-302$. [CrossRef] [PubMed]

48. Friel, S.; Barosh, L.J.; Lawrence, M. Towards healthy and sustainable food consumption: An Australian case study. Public Health Nutr. 2013, 17, 1156-1166. [CrossRef] [PubMed]

49. Pocol, C.B.; Marinescu, V.; Amuza, A.; Cadar, R.-L.; Rodideal, A.A. Sustainable vs. Unsustainable Food Consumption Behaviour: A Study among Students from Romania, Bulgaria and Moldova. Sustainability 2020, 12, 4699. [CrossRef]

50. Gerber, P.J.; Steinfeld, H.; Henderson, B. Tackling Climate Change through Livestock: A Global Assessment of Emissions and Mitigation Opportunities. Available online: http://www.fao.org/docrep/018/i3437e/i3437e.pdf (accessed on 6 October 2020). 
51. Hyland, J.J.; Henchion, M.; McCarthy, M.; McCarthy, S.N. The climatic impact of food consumption in a representative sample of Irish adults and implications for food and nutrition policy. Public Health Nutr. 2017, 20, 726-738. [CrossRef] [PubMed]

52. Pingali, P. Chapter 45-Policies for Sustainable Food Systems. In Sustainable Food and Agriculture; Academic Press: Cambridge, MA, USA, 2019; pp. 509-521.

53. Garnett, T. Where are the best opportunities for reducing greenhouse gas emissions in the food system (including the food chain)? Food Policy 2011, 36, S23-S32. [CrossRef]

54. Chance, Z.; Gorlin, M.; Dhar, R. Why Choosing Healthy Foods is Hard, and How to Help: Presenting the 4Ps Framework for Behavior Change. Cust. Needs Solut. 2014, 1, 253-262. [CrossRef]

55. Hallström, E.; Röös, E.; Börjesson, P. Sustainable meat consumption: A quantitative analysis of nutritional intake, greenhouse gas emissions and land use from a Swedish perspective. Food Policy 2014, 47, 81-90. [CrossRef]

56. van Dooren, C.; Marinussen, M.; Blonk, H.; Aiking, H.; Vellinga, P. Exploring dietary guidelines based on ecological and nutritional values: A comparison of six dietary patterns. Food Policy 2014, 44, 36-46. [CrossRef]

57. Burlingame, B.; Dernini, S. Sustainable diets: The Mediterranean diet as an example. Public Health Nutr. 2011, 14, 2285-2287. [CrossRef]

58. Vermeir, I.; Verbeke, W. Sustainable food consumption among young adults in Belgium: Theory of planned behaviour and the role of confidence and values. Ecol. Econ. 2008, 64, 542-553. [CrossRef]

59. Bryła, P. The development of organic food market as an element of sustainable development concept implementation. Probl. Ekorozw. 2015, 10, 79-88.

60. Borrello, M.; Caracciolo, F.; Lombardi, A.; Pascucci, S.; Cembalo, L. Consumers' Perspective on Circular Economy Strategy for Reducing Food Waste. Sustainability 2017, 9, 141. [CrossRef]

61. Stancu, V.; Haugaard, P.; Lähteenmäki, L. Determinants of consumer food waste behaviour: Two routes to food waste. Appetite 2016, 96, 7-17. [CrossRef]

62. Kasavan, S.; Mohamed, A.F.; Abdul-Halim, S. Drivers of food waste generation: Case study of island-based hotels in Langkawi, Malaysia. Waste Manag. 2019, 91, 72-79. [CrossRef] [PubMed]

63. Papargyropoulou, E.; Lozano, R.; Steinberger, J.; Wright, N.; Ujang, Z.b. The food waste hierarchy as a framework for the management of food surplus and food waste. J. Clean. Prod. 2014, 76, 106-115. [CrossRef]

64. Quested, T.E.; Marsh, E.; Stunell, D.; Parry, A.D. Spaghetti soup: The complex world of food waste behaviours. Resour. Conserv. Recycl. 2013, 79, 43-51. [CrossRef]

65. Hartmann, C.; Dohle, S.; Siegrist, M. Importance of cooking skills for balanced food choices. Appetite 2013, 65, 125-131. [CrossRef]

66. Baudry, J.; Péneau, S.; Allès, B.; Touvier, M.; Hercberg, S.; Galan, P.; Amiot, M.-J.; Lairon, D.; Méjean, C.; Kesse-Guyot, E. Food Choice Motives When Purchasing in Organic and Conventional Consumer Clusters: Focus on Sustainable Concerns (The NutriNet-Santé Cohort Study). Nutrients 2017, 9, 88. [CrossRef]

67. Fanelli, R.M.; Florio, A. Di Domestic food waste, gap in times of crisis. Ital. Rev. Agric. Econ. 2016, 71, 111-125. [CrossRef]

68. Rogers, K.; Cosgrove, A. Future Consumer Index: How COVID-19 Is Changing Consumer Behaviors. Available online: https://www.ey.com/en_id/covid-19/enterprise-resiliency-nine-areas-of-focus-for-covid19-crisis-management (accessed on 20 June 2020).

69. Hubbub How Has Covid-19 Changed Our Eating Habits? Available online: https://www.hubbub.org.uk/ blog/how-has-covid-19-changed-our-eating-habits (accessed on 22 April 2020).

70. Datassential. Coronavirus and The Impact on Eating. 2020. Available online: https://datassential.com/wpcontent/uploads/2020/03/Datassential-Coronavirus-3-12-20.pdf (accessed on 12 March 2020).

71. Hunter. The Impact of COVID-19 on Americans' Food Habits FOOD STUDY 2020. Available online: https://www.hunterpr.com/foodstudy_coronavirus/ (accessed on 9 April 2020).

72. Coffey, C.; Doorley, K.; O'Toole, C.; Roantree, B. The Effect of the COVID-19 Pandemic on Consumption and Indirect Tax in Ireland; ESRI: Dublin, Ireland, 2020.

73. Andersen, A.L.; Hansen, E.T.; Johannesen, N.; Sheridan, A. Pandemic, Shutdown and Consumer Spending: Lessons from Scandinavian Policy Responses to COVID-19. arXiv 2020, arXiv:2005.04630. Available online: https://arxiv.org/abs/2005.04630 (accessed on 10 May 2020). 
74. Piek, L. Changing Consumer Preferences and Grocery Sales During COVID-19. Available online: https: //kerry.com/insights/kerrydigest/2020/grocery-sales-during-covid-19 (accessed on 1 April 2020).

75. Schmidt, C.; Goetz, S.; Rocker, S.; Tian, Z. Google Searches Reveal Changing Consumer Food Sourcing in the COVID-19 Pandemic. J. Agric. Food Syst. Community Dev. 2020, 9, 1-8. [CrossRef]

76. Devitt, A. Comfort Food during COVID-19. Available online: https://kerry.com/insights/kerrydigest/2020/ comfort-food-during-covid-19 (accessed on 24 April 2020).

77. Traldi, V. Worldwide Food and Beverage Trends Follow Similar Pattern during COVID-19. Available online: https://kerry.com/insights/kerrydigest/2020/food-and-beverage-trends-covid-19 (accessed on 5 October 2020).

78. Li, J.; Hallsworth, A.G.; Coca-Stefaniak, J.A. Changing Grocery Shopping Behaviours among Chinese Consumers at The Outset Of The COVID-19 Outbreak. Tijdschr. Econ. Soc. Geogr. 2020, 6. [CrossRef]

79. Ipsos. Optimism and Anxieties during COVID-19 Outbreak. Available online: https://www.ipsos.com/ sites/default/files/2020-03/optimism_and_anxieties_during_covid-19_outbreak_0312_en.pdf (accessed on 13 March 2020).

80. OECD. OECD Scheme for the Application of International Standards for Fruit and Vegetables Preliminary Report: Evaluation of the Impact of the Coronavirus (COVID-19) on Fruit and Vegetables Trade; OECD: Paris, France, 2020.

81. MAPA Agricultura, Pesca y Alimentación Constata una Moderación en el Volumen de Compra de Alimentos. Available online: https:/www.lamoncloa.gob.es/serviciosdeprensa/notasprensa/agricultura/Paginas/2020/ 310320compra-alimentos.aspx (accessed on 31 March 2020).

82. ISMEA. Fruit Price Index. Available online: http://www.ismeamercati.it/ortofrutta/frutta-in-guscio (accessed on 21 July 2020).

83. Italiani.coop. Rapporto Coop 2020. Survey Post Covid-19-La Nuova Normalità degli Italiani [Coop 2020 Report. Survey Post Covid-19_The New Normality of Italians]. 2020. Available online: https://www.italiani.coop/ postcovid19-la-nuova-normalita-degli-italiani/ (accessed on 15 July 2020).

84. Kelkar, N. COVID-19 Impact: Permanent Shift in Consumer Preferences to Home, Personal Hygiene Products. Available online: https:/www.theweek.in/news/biz-tech/2020/04/23/covid-19-impact-permanent-shift-inconsumer-preferences-to-home-personal-hygiene-products.html (accessed on 23 April 2020).

85. Muscogiuri, G.; Barrea, L.; Savastano, S.; Colao, A. Nutritional recommendations for CoVID-19 quarantine. Eur. J. Clin. Nutr. 2020, 12, 6973. [CrossRef]

86. Butler, M.J.; Barrientos, R.M. The impact of nutrition on COVID-19 susceptibility and long-term consequences. Brain. Behav. Immun. 2020. [CrossRef]

87. Hassen, B.T.; el Bilali, H.; Allahyari, M.S. Impact of COVID-19 on Food Behavior and Consumption in Qatar. Sustainaibility 2020, 12, 6973. [CrossRef]

88. Scarmozzino, F.; Visioli, F. Covid-19 and the Subsequent Lockdown Modified Dietary Habits of Almost Half the Population in an Italian Sample. Foods 2020, 9, 675. [CrossRef]

89. Calder, P.C. Nutrition, immunity and COVID-19. BMJ Nutr. Prev. Health 2020, 3, 74-92. [CrossRef]

90. Langlois, P.L.; Lamontagne, F. Vitamin C for the critically ill: Is the evidence strong enough? Nutrition 2019, 60, 185-190. [CrossRef]

91. di Renzo, L.; Gualtieri, P.; Pivari, F.; Soldati, L.; Attinà, A.; Cinelli, G.; Leggeri, C.; Caparello, G.; Barrea, L.; Scerbo, F.; et al. Eating habits and lifestyle changes during COVID-19 lockdown: An Italian survey. J. Transl. Med. 2020, 18, 229. [CrossRef]

92. Ruiz-Roso, M.B.; de Carvalho-Padilha, P.; Mantilla-Escalante, D.C.; Ulloa, N.; Brun, P.; Acevedo-Correa, D.; Arantes-Ferreira-Peres, W.; Martorell, M.; Aires, M.T.; de Oliveira-Cardoso, L.; et al. Covid-19 Confinement and Changes of Adolescent's Dietary Trends in Italy, Spain, Chile, Colombia and Brazil. Nutrients 2020, 12, 2289. [CrossRef] [PubMed]

93. Jayawardena, R.; Misra, A. Balanced diet is a major casualty in COVID-19. Diabetes Metab. Syndr. 2020, 14, 1085-1086. [CrossRef] [PubMed]

94. Grabia, M.; Markiewicz-Żukowska, R.; Puścion-Jakubik, A.; Bielecka, J.; Nowakowski, P.; Gromkowska-Kepka, K.; Mielcarek, K.; Socha, K. The Nutritional and Health Effects of the COVID-19 Pandemic on Patients with Diabetes Mellitus. Nutrients 2020, 12, 3013. [CrossRef] [PubMed]

95. Kuijpers, D.; Wintels, S.; Yamakawa, N. Reimagining Food Retail in Asia after COVID-19. Available online: https://www.mckinsey.com/industries/retail/our-insights/reimagining-food-retail-in-asia-aftercovid-19 (accessed on 1 April 2020). 
96. Romeo-Arroyo, E.; Mora, M.; Vázquez-Araújo, L. Consumer behavior in confinement times: Food choice and cooking attitudes in Spain. Int. J. Gastron. Food Sci. 2020, 21, 100226. [CrossRef]

97. Gilsenan, K. Coronavirus: The Impact on Buying Behaviors. Available online: https://blog.globalwebindex. com/trends/coronavirus-impact-buying-behaviors/ (accessed on 30 March 2020).

98. Jones, K. These Charts Show How COVID-19 Has Changed Consumer Spending around the World. Available online: https://www.weforum.org/agenda/2020/05/coronavirus-covid19-consumers-shoppinggoods-economics-industry (accessed on 2 May 2020).

99. STATISTA Producer Price Index (PPI) of Agricultural Products in China. Available online: https://www. statista.com/statistics/275823/producer-price-index-of-agricultural-products-in-china/ (accessed on 5 October 2020).

100. FRBKC. Ag Finance Databook. Available online: https://www.kansascityfed.org/research/indicatorsdata/ agfinancedatabook (accessed on 10 October 2020).

101. Lusk, J. The Road from Farm to Table. Purdue University. Available online: https://ag.purdue.edu/stories/ the-road-from-farm-to-table/ (accessed on 10 October 2020).

102. Lusk, J. More Meat Market Madness. Available online: http://jaysonlusk.com/ (accessed on 28 April 2020).

103. Kirk, C.P.; Rifkin, L.S. I'll trade you diamonds for toilet paper: Consumer reacting, coping and adapting behaviors in the COVID-19 pandemic. J. Bus. Res. 2020, 117, 124-131. [CrossRef]

104. Sheth, J. Impact of Covid-19 on consumer behavior: Will the old habits return or die? J. Bus. Res. 2020, 117, 280-283. [CrossRef]

105. Wood, Z. Coronavirus Changing Shopping Habits "For Ever", Says M\&S Chief. Available online: https://www.theguardian.com/business/2020/may/20/coronavirus-changing-shopping-habitsforever-says-ms-chief (accessed on 20 May 2020).

106. Blundell, R.; Griffith, R.; Levell, P.; O'Connell, M. Could COVID-19 Infect the Consumer Prices Index? Fisc. Stud. 2020, 41, 1475-5890. [CrossRef]

107. Arora, N.; Pflumm, S.; Rodriguez, L.; Robinson, K.; Bhargava, S.; Charm, T.; Das, R.; Rishi, A.; Grimmelt, A.; Sexauer, C.; et al. Survey: US Consumer Sentiment during the Coronavirus Crisis. Available online: https://www.mckinsey.com/business-functions/marketing-and-sales/our-insights/surveyus-consumer-sentiment-during-the-coronavirus-crisis (accessed on 7 October 2020).

108. Sterman, J.D.; Dogan, G. "I'm not hoarding, I'm just stocking up before the hoarders get here.": Behavioral causes of phantom ordering in supply chains. J. Oper. Manag. 2015, 39, 6-22. [CrossRef]

109. Martin-Neuninger, R.; Ruby, M.B. What Does Food Retail Research Tell Us About the Implications of Coronavirus (COVID-19) for Grocery Purchasing Habits? Front. Psychol. 2020, 11. [CrossRef]

110. Bialkova, S.; Grunert, K.G.; van Trijp, H. From desktop to supermarket shelf: Eye-tracking exploration on consumer attention and choice. Food Qual. Prefer. 2020, 81, 103839. [CrossRef]

111. Irvine, M. 4 Major Trends Caused by COVID-19 and How to Respond. Available online: https://www. wordstream.com/blog/ws/2020/03/23/covid-19-business-trends (accessed on 2 July 2020).

112. Chen, H.; Qian, W.; Wen, Q. The Impact of the COVID-19 Pandemic on Consumption: Learning from High Frequency Transaction Data. SSRN Electron. J. 2020, 1. [CrossRef]

113. Dunn, A.; Hood, K.; Driessen, A.; Bureau, U.S.; Analysis, E. BEA Working Paper Series, WP2020-5 Measuring the Effects of the COVID-19 Pandemic on Consumer Spending Using Card Transaction Data. Bur. Econ. Anal. 2020, 5, 1-22. [CrossRef]

114. Baker, S.R.; Farrokhnia, R.A.; Meyer, S.; Pagel, M.; Yannelis, C.; Catherine, S.; Hoxby, C.; Koijen, R.; Parker, J.; Sufi, A.; et al. How Does Household Spending Respond to an Epidemic? Consumption During the 2020 COVID-19 Pandemic. Rev. Asset Pricing Stud. 2020, 9.

115. Aislelabs, I. How Shopping Centres Globally Are Responding to Coronavirus by Aislelabs. Available online: https://www.aislelabs.com/blog/2020/03/23/how-shopping-centres-responding-coronavirus/ (accessed on 23 March 2020).

116. Bounie, D.; Camara, Y.; Galbraith, J.W. Consumers' Mobility, Expenditure and Online-Offline Substitution Response to COVID-19: Evidence from French Transaction Data. IDEAS 2020. [CrossRef]

117. Nicola, M.; Alsafi, Z.; Sohrabi, C.; Kerwan, A.; Al-Jabir, A.; Iosifidis, C.; Agha, M.; Agha, R. The Socio-Economic Implications of the Coronavirus and COVID-19 Pandemic: A Review. Int. J. Surg. 2020. [CrossRef]

118. Chauhan, V.; Shah, M.H. An Empirical Analysis into Sentiments, Media Consumption Habits, and Consumer Behaviour during the Coronavirus (COVID-19) Outbreak. Purakala 2020, 31, 353-375. [CrossRef] 
119. Intelligence, N. The Impact of COVID-19 on Consumer Behavior. Available online: https://www.numerator. com/resources/blog/impact-covid-19-consumer-behavior (accessed on 13 March 2020).

120. Oaklander, M. Our Diets Are Changing Because of the Coronavirus Pandemic. Is It for the Better? Available online: https://time.com/5827315/coronavirus-diet/ (accessed on 28 April 2020).

121. Borsellino, V.; Schimmenti, E.; el Bilali, H. Agri-Food Markets towards Sustainable Patterns. Sustainability 2020, 12, 2193. [CrossRef]

122. FAO. Mitigating Risks to Food Systems during COVID-19: Reducing Food Loss and Waste; FAO: Rome, Italy, 2020.

123. Abeliotis, K.; Lasaridi, K.; Chroni, C. Attitudes and Behaviour of Greek Households Regarding Food Waste Prevention. Waste Manag. Res. 2014, 32, 237-240. [CrossRef]

124. Martinengo, M.C. Household food waste and consumer culture: Reflections on Italian behaviour. J. Nutr. Ecol. Food Res. 2014, 2, 73-77. [CrossRef]

125. Coldiretti-SWG. Italiani e Alimentazione nel Tempo della Crisi Indagine Coldiretti/SWG. Available online: https://www.napoli.coldiretti.it/italiani-e-alimentazione-nel-tempo-della-crisi-indagine-coldirettiswg-ottobre-2011.aspx?KeyPub=GP_CD_NAPOLI_HOME\%7CCD_NAPOLI_HOME\&Cod_Oggetto= 30584835\&subskintype=Detail (accessed on 16 July 2020).

126. Grant, K. Covid-19 and Cooking: Consumers Will Seek to Avoid Food Waste 'Far Beyond' Pandemic. Available online: https://inews.co.uk/news/covid-19-cooking-consumers-will-avoid-food-waste-pandemic-424360 (accessed on 4 May 2020).

127. Neff, R.A.; Spiker, M.L.; Truant, P.L. Wasted Food: U.S. Consumers' Reported Awareness, Attitudes, and Behaviors. PLoS ONE 2015, 10, e0127881. [CrossRef]

128. van Geffen, L.; van Herpen, E.; van Trijp, H. Household Food Waste-How to Avoid It? An Integrative Review. In Food Waste Management: Solving the Wicked Problem; Närvänen, E., Mesiranta, N., Mattila, M., Eds.; Springer: Berlin/Heidelberg, Germany, 2020; pp. 27-55.

(C) 2020 by the authors. Licensee MDPI, Basel, Switzerland. This article is an open access article distributed under the terms and conditions of the Creative Commons Attribution (CC BY) license (http://creativecommons.org/licenses/by/4.0/). 